\title{
Epistemología del pensamiento visual contemporáneo desde el imaginario transdisciplinario*
}

\author{
Javier Ávila** \\ Carolina Acosta***
}

Recibido: 2015-06-11 Enviado a pares: 2015-06-30

Aprobado por pares: 2015-07-30 Aceptado: 2015-08-04

\begin{abstract}
Resumen
El pensamiento visual contemporáneo trae consigo un campo nuevo de conocimiento. Los llamados estudios visuales implican nuevos problemas, que se caracterizan, a su vez, por niveles de complejidad inéditos y requerimientos transdisciplinarios de abordaje. Este estudio propone un análisis epistemológico a partir del problema de la construcción de la realidad, en su relación con el imaginario y el régimen escópico. En este sentido, se insiste en la apertura al estudio de la visualidad -sobre todo- desde una perspectiva compleja y transdisciplinaria.

Palabras clave: pensamiento visual contemporáneo, epistemología, construcción de la realidad, imaginario, régimen escópico, transdisciplina, tecnología, complejidad.
\end{abstract}

* Artículo elaborado en el marco de la investigación "La construcción del imaginario de juventud a partir del relato mediático publicitario: el caso de la Fundación universitaria Los Libertadores". Facultades de Comunicación y Psicología de la Institución Universitaria Los Libertadores, Bogotá, Colombia, 2015.

** Candidato a doctor en Transdisciplina por parte del Centro de Estudios Avanzados del Instituto Politécnico Nacional (CINVESTAV) de México. javilac@cinvestav.mx

*** Magíster en Psicoanálisis, Subjetividad y Cultura, de la Universidad Nacional de Colombia. Docente de Tiempo Completo de la Facultad de Psicología de la Institución Universitaria Los Libertadores, Bogotá, Colombia. cpacostam@libertadores.edu.co 


\title{
Epistemology of the Contemporary Visual Thought from the transdisciplinary imaginary
}

\begin{abstract}
The Contemporary Visual Thought brings along with a new field of knowledge. The visual studies imply new problems that are characterized at the same time by unknown complex levels and transdisciplinary requirements of approach. This study proposes an epistemological analysis since the problem of constructing the reality in its relationship with the imaginary and the scopic regime. In this sense it is insisted on the opening of the visuality study above all from a complex and transdisciplinary perspective.
\end{abstract}

Key words: Contemporary Visual Thought, Epistemology, Construction of the Reality, Imaginary, Scopic Regime, Transdisciplinary, Technology, Complexity.

\section{Epistemologia do Pensamento Visual Contemporáneo desde o imaginário transdisciplinario}

\section{Resumo}

O Pensamento Visual Contemporáneo traz consigo um campo novo de conhecimento. Os chamados estudos visuais implicam novos problemas, que se caracterizam a sua vez pelos níveis de complexidade inéditos e requerimientos transdisciplinários de abordagem. O presente estudo propõe um análise epistemológico a partir do problema da construção da realidade, em sua relação com o imaginário e o regime escópico. Neste sentido, se insiste na abertura ao estudo da visualidade -especialmente- desde uma perspetiva complexa e transdisciplinar.

Palavras-chave: Pensamento Visual Contemporáneo, Epistemologia, Construção da Realidade, Imaginário, Regime Escópico, Transdisciplina, Tecnologia, Complexidade 


\section{Introducción}

Una imagen que ya no es un objeto más, pura re-presentación, re-vestimento de lo real. Una imagen que habla, que incluso piensa, resonancia inevitable de aquella asombrosa afirmación de Godard acerca del cine: una forma que piensa. Así se reveló la imagen en el proceso de reflexión volcado en las siguientes líneas; proceso conducido, no tanto por una pretensión de desnudar los imaginarios construidos por un grupo de jóvenes frente al relato mediático publicitario contenido en un conjunto de pautas comerciales, sino más bien por el gesto mismo de criticar esa pretensión y de entablar, ahora sí, un diálogo con lo que en ella vacila, tropieza: ¿cómo describir un imaginario sin un criterio epistemológico propiamente visual? ¿Desde dónde construir tal criterio?

Si la imagen piensa, si ya no se la considera oscura (obtusa, meramente pensada, objeto de una conciencia completamente separada de ella), es necesario también concebir su implicación directa, o más bien, su envés: una epistemología de la visualidad que dé cuenta de la manera en que es posible el conocimiento a partir de lo visual, entendido no solamente como el proceso perceptivo por el cual los ojos traen las imágenes de la realidad al interior del sujeto (primera de una extensa cadena de pasos que explican la re-presentación del mundo), sino también, y principalmente, como todo un complejo sociocultural en el que las imágenes se construyen y se validan, más acá y más allá de los órganos de los sentidos, en las redes significantes tejidas por las comunidades humanas.

En este orden de ideas, no hay mejor terreno para que una epistemología de la visualidad siente sus bases, que el imaginario transdisciplinario, considerado como campo de fuerzas provenientes de diversas áreas del conocimiento y de la acción, que reúne las características del concepto de imaginario propuesto por el psicoanálisis: producción de significaciones colectivas, capacidad incesante de inventar lo nuevo; al mismo tiempo, el imaginario transdisciplinario no desconoce el extrañamiento propio de toda construcción sociocultural, idea más acorde con la tradición lacaniana. Es aquí, en esta intersección entre creatividad radical y alienación radical, a la que nos referiremos más adelante, en donde se ubica el imaginario transdisciplinario como metáfora de la colaboración interepistémica en torno a la comprensión de la visualidad contemporánea.

\section{Metodología}

En "La construcción del imaginario de juventud a partir del relato mediático publicitario. El caso Los Libertadores", investigación en la que se enmarca esta reflexión, se empleó la técnica de grupos focales para acercarse al discurso (lenguaje verbal y no verbal) de un grupo de estudiantes de la institución universitaria nombrada, acerca de un conjunto de pautas publicitarias televisivas de gran recordación entre ellos, con el fin de identificar los imaginarios sociales de juventud construidos en torno a los contenidos de las pautas.

Estas pautas, a su vez, fueron escogidas atendiendo a los resultados de un sondeo inicial en el que se indagó en estudiantes de distintos semestres de la comunidad universitaria acerca de los comerciales televisivos más recordados durante los últimos cinco años y significantes ligados a la palabra "juventud", entre otros aspectos. 
Los grupos focales se formaron por muestreo intencional, atendiendo al carácter cualitativo del diseño metodológico. Se llevaron a cabo cuatro grupos focales, uno de diez integrantes y tres de doce, con duraciones que oscilaron entre 60 y 180 minutos cada uno. Todas las sesiones se grabaron, previo consentimiento de los participantes; no obstante, en ellas se realizó observación directa y anotación de los gestos y comentarios más relevantes, con el fin de no perder algún detalle que resultara provechoso para el análisis.

El análisis del discurso se hizo a partir de un grupo de categorías conceptuales extraídas del marco teórico (sentimental, significación, asociaciones verbales, práctica social, identificación con la marca, motivacional, estereotipos y prejuicios, invisibilización y adultocentrismo), pero durante el proceso fue surgiendo una serie de categorías emergentes, articulaciones conceptuales y sobre todo, un cuestionamiento hacia la metodología misma (producto de las distintas posturas de los investigadores), que resultaron muy interesantes a la hora de proponer las conclusiones y de nutrir la discusión que convocó este proyecto, en donde el disenso jugó un papel fundamental.

\section{Epistemología de la visualidad}

Para dar cuenta de la complejidad que entraña una epistemología de la visualidad, partimos de la siguiente definición de epistemología:

La epistemología consiste en el estudio de la constitución de objetos válidos [...] la tarea epistemológica, al preocuparse por las condiciones del conocimiento válido, supone una referencia a la validez normativa [...] implica una evaluación de las partes respectivas del sujeto y del objeto en la constitución de esos conocimientos (Hernández y Rodríguez, 2003, p. 132).

A partir de la anterior cita, identificamos que la epistemología estudia la validez del conocimiento en sus condiciones de validación. Tales condiciones permiten entender el compromiso que la epistemología adquiere con la constitución del conocimiento, más allá de la configuración del vínculo sujeto-objeto, en el sentido de la percepción del mundo. Cabe insistir que la percepción del mundo ya no alude aquí a la pregunta sobre la veracidad del conocimiento, sino al proceso de su construcción.

La pregunta por el conocimiento nos remite al problema de la percepción, en el sentido de un cuerpo que interactúa con un mundo. La percepción del mundo sería, desde tal perspectiva, el resultado de cierta forma de mirar ligada ineludiblemente a los sentidos, mientras, la percepción del mundo como proceso de construcción del conocimiento hace énfasis en las maneras en que dicho conocimiento se configura y se valida en el seno de las comunidades (artísticas, culturales, científicas) que lo discuten, lo debaten y lo ratifican, no precisamente por consenso. Este énfasis no solo supera la tradicional oposición entre empirismo y racionalismo en el sentido clásico kantiano, sino también la tensión entre sujeto y objeto, y las consecuentes posiciones de tal tensión resultantes: lo subjetivo (falso, ilusorio, pendiente de validación) y lo objetivo (verdadero, válido en sí). 
Dado que "resulta imposible manejar cualquier tesis epistemológica sin considerar la perspectiva preteórica desde la cual fue planteada y por eso las discusiones entre perspectivas diferentes (como es el caso entre realismo e idealismo, por ejemplo) resultan lógicamente irresolubles" (Padrón, 2007, p. 3), ya que provienen precisamente de la puesta en escena de filtros preteóricos y precognitivos sobre qué es el conocimiento y cómo se obtiene, la pregunta por los procesos mediante los cuales se construye y se valida el conocimiento, en contraposición a la pregunta por su veracidad, es plenamente relevante.

Una postura así, que más que ser conciliadora pretende omitir tensiones desgastantes, no resulta, sin embargo, incompatible con planteamientos como los de Gastón Bachelard, para quien, en la línea "negociadora" entre presumibles opuestos epistemológicos, el pensamiento científico ha de

[...] girar en torno a la doble alternancia entre lo a priori y lo a posteriori, entre matemática y física, entre racionalismo y empirismo, a los que considera ligados, dentro del pensamiento científico, por un extraño lazo, porque si el empirismo necesita ser comprendido, el racionalismo necesita ser aplicado (Bachelard, 1978, citado por Martínez Velasco, 1992, p. 79).

En este camino, entre metateórico/metalingüístico y conciliador, la epistemología de la visualidad investiga cómo se visibiliza de cierta manera, en su doble vertiente de percepción visual y de construcción social, el mundo, cómo se construye la percepción y se convierte en algo así como realidad. Ahora bien, la realidad como construcción nos conduce a nuevos problemas, a partir del reconocimiento de las condiciones contemporáneas de la visibilidad:

Más de medio siglo de minuciosos trabajos experimentales muestran que la "percepción" de los objetos como tales, distribuidos en el espacio y con una cierta continuidad en el tiempo, si bien es temprana en los niños, no es innata. El espacio y el tiempo "dentro" del cual se ubican los objetos que constituyen nuestra experiencia cotidiana, requieren un largo proceso de elaboración [...] requiere de mucha experiencia acumulada para poder ser percibido (García, 2008, p. 42).

Los estudios sobre visualidad contemplan, entonces, la complejidad que implica percibir algo; el tiempo y el espacio, desde esta visión, son construcciones cotidianas que ni están ya ahí, como estructuras innatas, ni se dan de una vez y para siempre: la experiencia las configura y reconfigura continuamente como realidad. La complejidad del asunto de la construcción de la realidad descansa sobre la consideración de tal realidad como una densa red de conexiones de las cuales puede detectarse no su verdad, sino su visibilidad; entonces, la validez de estas conexiones no consiste en su carácter verdadero o falso, sino en la legitimidad que han adquirido en la vida cotidiana, por el régimen de visibilidad que se juega ahí. La validez normativa aquí no es una unificación o consenso, sino una red compleja de conexiones:

Condiciones de posibilidad [...] relativo a su dominio de objetos, al tipo de lenguaje que utiliza, a los conceptos que dispone o que procura establecer; define las reglas formales y semánticas que se requieren para que un enunciado pueda pertenecer a esa ciencia [...] Está constituido por un campo de conjuntos 
discursivos que no tienen ni el mismo estatuto, ni el mismo recorte, ni la misma organización, ni el mismo funcionamiento que las ciencias a las cuales da lugar (Foucault, 2013, p. 257).

La importancia que adquiere la epistemología en los estudios visuales tiene que ver con el problema de la visibilidad, pues la visibilidad está ligada a la validez del conocimiento y de la percepción de la realidad. En este orden de ideas, las implicaciones lógicas, en el sentido plenamente filosófico del término, no se hacen esperar: el análisis del lenguaje y de los conceptos de los que se dispone, la disputa de los campos discursivos, los recortes en la realidad (los campos del conocimiento) y las organizaciones a ellos vinculados nos permiten vislumbrar un régimen escópico: una forma de ver el mundo, una formación de imágenes que se organizan de cierta manera y producen el mundo: algo así como una normativa de ver la realidad.

La expresión régimen escópico pone de manifiesto que

[...] la constitución del campo escópico es cultural o, digamos, está sometida a construcción, a historicidad y culturalidad, al peso de los conceptos y categorías que lo atraviesan. $\mathrm{O}$, dicho de otra forma, y resumiendo finalmente: que el ver no es neutro ni, por así decir, una actividad dada y cumplida en el propio acto biológico, sensorial o puramente fenomenológico. Sino un acto complejo y cultural y políticamente construido, y que lo que conocemos y vemos en él depende, justamente, de nuestra pertenencia y participación de uno u otro régimen escópico - para utilizar una noción que debe su elaboración reciente, como es bien sabido, a Martin Jay, y acaso anteriormente a la reflexión de Michel Foucault (Brea, 2007 p. 148).

En Martin Jay, el asunto está ligado a la posible primacía de la visualidad para desentrañar verdades que escapan a (o más bien, que no son efecto de) los regímenes discursivos. En tal sentido, uno de los cuestionamientos que plantea Jay es: "¿̇argumentó Foucault que la visualidad pudo de algún modo establecer una táctica alrededor de la discursividad y proveer una base para una verdad que no fuera meramente un efecto de un régimen discursivo específico?" (Jay, 2007 p. 16). Pareciera que Jay apunta, con su pregunta, al deslinde de los regímenes visuales de los discursivos en cuanto a su potencial veracidad; no obstante, tras un análisis detenido de las afirmaciones de Foucault, Jay responde que no hay tal deslinde y que los regímenes visuales son tan "mentirosos" como los discursivos: tan ligados a las condiciones hegemónicas de producción, reproducción y legitimación como los últimos, y tan huérfanos de una veracidad que pudiera afirmarse prístina en relación con ellos.

La visualidad puede ser entendida, entonces, por un lado, como percepción, ya que es innegable que "la observación ha tenido, durante siglos, un papel medular en la discusión epistemológica" (Hernández y Rodríguez, 2003, p. 84), y por otro, como régimen escópico, es decir, como régimen de validez perceptual:

Sabemos esto en relación con la familia; y sabemos que la universidad, y, de un modo general, todos los sistemas de enseñanza, que al parecer sólo diseminan 
conocimiento, se utilizan para mantener a cierta clase social en el poder y para excluir a otra de los instrumentos de poder. Las instituciones del saber, de la previsión y del cuidado, como la medicina, también ayudan a apuntalar el poder político. Esto también es evidente, incluso a un nivel escandaloso, en ciertos casos vinculados con la psiquiatría [...] desenmascarar la violencia política que se ha ejercido a través de estas de manera oculta, para que podamos combatirlas $[\ldots]$ hay centros y puntos de apoyo invisibles y poco conocidos; su verdadera resistencia, su verdadera solidez quizá se encuentra en donde menos uno espera (Foucault, 2006, p. 59).

Lo que nos interesa señalar es la importancia de entender la epistemología de la visualidad como proceso que incluye desde la percepción como función fisiológica, por llamarlo de alguna manera, hasta la percepción como función de imágenes validadas históricamente, recreadas y actualizadas en las mismas vidas cotidianas de los cuerpos que perciben. Cuando decimos proceso y lo inscribimos en un cuerpo, entendemos la profunda imbricación entre régimen imaginario, esto es, el imaginario que habita en el cuerpo, con sus reglas subjetivas (alienadas o creativas) de formación de imágenes, producción individual y reproducción social, y régimen escópico, con las tensiones de poder a él inherentes.

La ligazón de los dos regímenes es relevante, pero también se trata de un terreno plagado de dudas. El régimen imaginario supone una disposición de las imágenes que el cuerpo coordina a partir, no de sí mismo, sino de otro; el problema de la imagen, que ante todo es la imagen de sí mismo, aquí es delicado, pues por un lado entraña esta carga del otro (a decir de Lacan, Yo soy otro), y por otra parte, queda abierto a la insuficiencia, por una fragmentación que es constituyente al sujeto y que lo hace presa fácil de la mirada:

La mirada marca el punto del objeto (el punto de la imagen) desde la cual el sujeto que se ve ya es mirado, es decir que el objeto me está mirando. Lejos de asegurar la presencia para sí del sujeto y su visión, la mirada funciona entonces como una mancha, una zona confusa que perturba la visibilidad transparente del cuadro e introduce una división irreductible en mi relación con la imagen" (Zizek, 2006, p. 210).

La mancha, esa zona confusa que perturba la visibilidad, ese punto de inversión del ámbito geometral cartesiano, da cuenta de la fragmentación, de la escición justamente operada por el lenguaje en el cuerpo, y es el lugar por donde se introduce la angustia en una escena que previamente ha sido cuidadosamente enmarcada como lugar de la observación del sujeto omnipotente hacia los objetos de la realidad. Cuando esa observación se devuelve en forma de mirada, ya no hay sujeto que se sostenga: el marco se destruye, la mirada rebasa al sujeto y lo convierte en objeto, el mundo se baja de la escena (si es que puede formularse así, siguiendo a Lacan'1), deja de ser realidad y se muestra real.

1 "La dimensión de la escena, en su división respecto del lugar, mundano o no, cósmico o no, donde se encuentra el espectador, está ahí ciertamente para ilustrar ante nuestros ojos la distinción radical entre el mundo y aquel lugar donde las cosas, aun las cosas del mundo, acuden a decirse. Todas las cosas del mundo entran en escena de acuerdo con las leyes del significante, leyes que no podemos de ningún modo considerar en principio homogéneas a las del mundo" (Lacan, 2006, p.43). Por otra parte, "Una vez que la escena prevalece, lo que ocurre es que el mundo entero se sube a ella, y que con Descartes se 
Entonces, la visualidad misma no es infalible, pues el sujeto que la detenta (o más bien, el sujeto detentado en el momento de la mirada) se caracteriza por la precariedad, por la imposibilidad de una madurez en términos de acabamiento y sobre todo, por una dependencia, primero del otro-prójimo y luego del Otro-simbólico, como fuentes de imágenes y de significantes para formar sus propias imágenes y enunciados. En estos términos, el registro imaginario subjetivo surge como manera de conjurar esa mirada, de protegerse de ella, y por ende, de lo real que late tras la misma.

El régimen imaginario como forma obcecada del sujeto de pretender darse a sí mismo las reglas de formación de las imágenes de la realidad es, desde esta perspectiva, velo, marco, forma de apaciguar a los objetos cuando miran desde el mundo y sobre todo, narcótico ante la alienación de la mirada del Otro. Este régimen imaginario, al depender del otro y del Otro, inevitablemente entra en contacto con los regímenes escópicos que cimientan los modos de visualidad de una época; es decir, el imaginario transita desde lo subjetivo, hacia una percepción-legitimación de la realidad más allá del cuerpo singular que percibe.

Esta tensión entre lo subjetivo y lo cultural, entre lo propio y lo ajeno, nos revela un nuevo problema: el ocultamiento como condición de régimen escópico. La función de un régimen escópico, para seguir funcionando y regulando, es no hacerse visible, es decir, invisibilizarse como modo de ocultamiento del régimen mismo; esto que se invisibiliza, por un lado, es una violencia política que, al naturalizarse como realidad, se legitima en la vida cotidiana de los cuerpos de la percepción. Por otro lado, se invisibilizan los efectos de la mirada, lo que vuelve confusa la relación con la imagen: creo mirar, pero en el momento menos pensado, ese Otro régimen escópico me mira.

\section{a. Visualidad}

La visualidad, en sentido epistemológico, se compromete con el qué vemos y cómo lo vemos. Sucede que cualquier acto de ver descansa sobre una lógica sociocultural, que muchas veces, por efectos de la cotidianidad, se nos presenta como algo natural; el naturalismo, en términos epistemológicos, consiste en cierta inmediatez del sentido común, que no logra cuestionar o visibilizar los procesos históricos mediante los cuales se construye la realidad.

Este naturalismo nos da la sensación que eso que estamos mirando es eterno e inmutable y posee características que tienen que ver con su ser, es decir, rasgos ontológicos; es, entonces, cuando formulamos enunciados naturales y ontológicos: "Los procesos no son observables, son inferidos sobre la base de observables". (García, 2008, p. 164). Cuando decimos que los procesos no son observables, estamos tomando como modelo lo observable, queriendo decir con ello que los procesos a los que nos referimos no

puede decir Sobre la escena del mundo, yo avanzo, como él hace, larvatus, enmascarado" (Lacan, 2006, p.44). Estas dos citas aluden a la diferencia del mundo (lo real, casi en sentido nouménico kantiano) y la escena (la enmarcación simbólica del mundo, la representación, el juego simbólico-imaginario de capas y veladuras que hacen que vérselas directamente con el mundo sea imposible). 
aparecen directamente delante de nuestra percepción, no hacen parte del mundo como tal, sino que obedecen a algo en nosotros que es del orden de nuestras experiencias previas.

La reflexión epistemológica nos revela el agotamiento del naturalismo, un naturalismo que tuvo la intención de trabajar con hechos, identificar leyes que tuvieran el estatuto de mandatos naturales y utilizar el mismo método que las ciencias físicas (Hacking, 2006, p. 68). El naturalismo es la epistemología que supone una percepción pura que conoce la naturaleza; esta seguridad se apoya en una suerte de certeza sobre una realidad dada, que se sostiene desde la comprobación o la falsedad, una realidad que supone la percepción correcta del mundo, antes que su complejidad:

El discurso ritual, el discurso cargado de poderes y de peligros se ordenaba poco a poco hacia una separación entre el discurso verdadero y el discurso falso. Me situaré después en el paso del siglo XVI al siglo XVII, en la época en que aparece, en Inglaterra, sobre todo, una ciencia de la mirada, de la observación, de la atestiguación, cierta filosofía natural inseparable sin duda de la instauración de nuevas estructuras políticas, inseparable, también, de la ideología religiosa: nueva forma, seguramente de la voluntad de saber [...] apoyándose primero en la historia natural, a continuación, en la anatomía y la biología (Foucault, 2009, pp. 61 y 63).

La ciencia moderna, la ciencia de la mirada, no está en los laboratorios o en las universidades, sino que está articulada como régimen escópico en la vida cotidiana, en la percepción de los cuerpos. Lo que Foucault señala en la cita previa son los momentos finos donde esta mirada se constituyó como régimen escópico que valida la relación de la observación con la atestiguación. En otras palabras, el régimen escópico implica una violencia política que se juega en estructurar la mirada de los cuerpos, en donde la observación anatómica de los mismos produce una forma supuestamente verdadera de conocer el mundo, una cognición con cierta estructura invisibilizada o voluntad de saber, que emplea la atestiguación como forma de conocimiento y que pretende ser conocimiento comprobado: en este sentido, conocimiento verdadero o falso.

En este orden de ideas, atestiguar y evidenciar (palabra que revela un vínculo etimológico más cercano al ver) son acciones que presumiblemente dan cuenta, con mayor propiedad, de la veracidad de lo percibido, pues

[...] ha habido una antigua relación, a menudo controvertida, entre visualidad y veracidad. En el marco jurídico, el testimonio del testigo ocular frecuentemente prevalece sobre lo solamente oído. La misma palabra evidencia, como ha sido apuntado a menudo, deriva del latín videre, ver. Metafórica o literalmente, muchas filosofías, idealistas tanto como empiristas, han privilegiado la iluminación, las luces, la transparencia, y la claridad en su búsqueda de la verdad. La teoría, cuya raíz se halla en la palabra griega theoria, ha sido a menudo relacionada con la experiencia visual de mirar a una representación teatral. De todos los sentidos, la visión ha parecido el más desinteresado por ser el más distanciado de lo que percibe (Jay, 2007, p. 9). 
La visualidad ingenua supone que la mirada se reduce a los ojos, a la mera proyección retiniana de las imágenes, y no al proceso histórico que la antecede, es decir, al imaginario y al régimen escópico que establecen las relaciones que hacen posible la percepción. La ingenuidad visual obvia "La naturaleza de relaciones implícitas, no visibles sino en momentos de un comportamiento particular que deriva de la emergencia de una nueva propiedad" (Amozurrutia, 2003, p. 45). Esto quiere decir que lo que está enfrente nuestro lo podemos ver como tal gracias a un proceso de conexiones previas, de relaciones implícitas, que por ser tan cotidianas nos parecen naturales; sin embargo, esta naturalidad de la percepción requiere una base de imágenes previas, un plano imaginario que sostiene la percepción.

En este punto entendemos que "En el proceso de conocimiento no hay observación pura, así como tampoco hay pura observación" (Hernández y Rodríguez, 2003, p. 110). No hay observación pura, porque miramos con imágenes previas; tampoco hay pura observación, porque nuestra mirada está atravesada por cierta forma histórica de ver, cierto acto de ver. Entonces, es importante señalar que la invisibilidad no consiste en un déficit fisiológico o neuronal, sino en un sesgo semiótico derivado de la falta de establecimiento de conexiones, que impide ver cierto plano de la realidad.

Este sesgo se oculta como parte del régimen escópico que opera sobre los imaginarios de los cuerpos, y puede aparecer también como mancha, cuando la realidad que observa el sujeto lo concierne hasta tal punto, que aflora lo real y le devuelve la mirada; esto último es lo que ocurre cuando, por ejemplo, etiquetamos con diagnósticos cuyos criterios sintomáticos nos damos cuenta que presentamos, o cuando los juicios de valor que emitimos nos hacen advertir nuestros tropiezos: vemos en nosotros el espasmo o el prejuicio que identificamos en otro y quedamos en evidencia. Ante esta situación, o huimos de la angustia y nos defendemos de ella acaparándonos tras la coraza de la conciencia cartesiana, o prestamos atención a la señal (de la angustia, tal y como la formuló Freud) y empezamos a complicar las relaciones subyacentes a la observación. No en vano, Lacan aisló la mirada y su envés (la mancha) como una función:

Si la función de la mancha es reconocida en su autonomía e identificada con la de la mirada, podemos buscar su rastro, su hilo, su huella, en todos los peldaños de la constitución del mundo en el campo escópico. Entonces nos daremos cuenta de que la función de la mancha y de la mirada lo rige secretamente y, a la vez, escapa siempre a la captación de esta forma de la visión que se satisface consigo misma imaginándose como conciencia (Lacan, 1995, p. 82).

El campo escópico, regido por la función de la mancha, se caracteriza entonces por una invisibilidad constitutiva, por una obtusidad necesaria a la observación diaria, que desconoce aquello que el cuerpo no percibe, o que registra como ajeno o alejado de su vida cotidiana; en este sentido, lo desconoce, lo deja en el campo de lo impensado: "Fulano carecía de teoría, de manera que en realidad ni siquiera percibió que tenía ante sí un dato real" (Muñoz-Martínez, 2003, p. 35). La insistencia epistemológica en la complejidad pasa por la necesidad de una formación teórica para desencadenar percepción de objetos de estudio, en el caso de la ciencia. Para el caso de los estudios visuales, la epistemología 
en el sentido de la visibilización de la invisibilidad, nos sirve para detectar el problema del régimen escópico, y, en consecuencia, entender la percepción misma como resultado de un proceso complejo, como un acto -performativo- de ver.

Asistimos a una complejidad que se localiza luego del agotamiento del naturalismo ingenuo, el cual supone observaciones puras cuando se percibe un objeto. Las implicaciones de tal localización son analizadas por Bachelard, para quien

La lógica no puede seguir siendo cosista ${ }^{2}$, debe reintegrar las cosas en el movimiento del fenómeno [...] Ante el pensamiento humano se presentan ahora otros objetos que no son estables, que no tendrían, en reposo, ninguna propiedad y por consiguiente ninguna definición conceptual. Sería indispensable, por lo tanto, modificar de alguna manera el juego de los valores lógicos (Bachelard, 2009, p. 104).

En esta cita, Bachelard llama la atención sobre dos puntos: por un lado, toda la construcción cognitiva que tiene que atravesar el cuerpo humano para generar representaciones del mundo, y por el otro, la carga histórica que produce espacios de cierta manera, y no de otra.

Apelamos, entonces, a la construcción de la realidad, bajo el supuesto (también construido) que la realidad no es algo dado o natural. Pareciera obvio que el pensamiento contemporáneo ha ya desmantelado la visión naturalista, pero lejos de ello, tal postura se oculta y se invisibiliza con más bríos cuanto más se la quiere desterrar. Ante la pregunta misma por la realidad y las consecuencias que derivaron de ella, no nos detenemos en la tarea de este desmantelamiento, ya que

En cuanto pudiéramos convencer a nuestro adversario realista que debe aceptar una realidad, que se presenta en capas, y distinguir niveles en sus argumentos, habríamos dado un paso importante en el desarrollo de nuestra crítica; porque ahora el impedir la mezcla de géneros, podríamos discutir en un nivel dado y no tendríamos dificultad en demostrar que, en un nivel dado, es precisamente el método el que define a los seres (Bachelard, 2009, p. 53).

El adversario realista tiene que ver con la epistemología del naturalismo, que supone una realidad dada o por descubrir; en cambio, distinguir en capas la realidad, y, sobre todo, asumir que el método es una construcción de objetos de estudio es lo que corresponde a la visión de la realidad como construcción. La mezcla de géneros, la discusión acerca del nivel dado de la realidad o acerca de los métodos desde los que se abordan las construcciones sobre tal realidad inauguran la pregunta por las formaciones del conocimiento, por la complejidad propia de los niveles que constituyen la realidad. Esta pregunta sigue resonando en el camino del señalamiento de inevitable "impureza" de la observación, ya que,

2 La lógica cosista tiene que ver con el debate kantiano sobre el supuesto de una realidad en sí, a la que la ciencia o la filosofía tendría que dedicar sus esfuerzos por descubrirla. Sin embargo, desde el mismo Kant la realidad se nos revela como representación que se liga con un imaginario, y con una construcción desde diferentes niveles de sentido (Kant, 2006). 
[...] aunque el valor del experimento ha sido objeto de prolijos análisis por parte de la filosofía de la ciencia, son pocos los trabajos que hay sobre la observación, y ciertamente estos análisis han puesto en duda la pureza de la observación, su posibilidad de ser objetiva, o han condenado la carga ideológica y cultural de quien la ejerce (Hernández y Rodríguez, 2003, p. 83).

Esta interacción densa entre niveles, que se detecta desde un nuevo posicionamiento epistemológico que no opera desde el supuesto de la realidad dada o natural, exige asumir la realidad como una construcción, desde una complejidad que investiga cómo se forma dicha realidad. En este sentido, la epistemología, entendida como el análisis de los procesos de formación del conocimiento y de la realidad que se produce a partir de estos procesos se liga a la ruptura con el método científico, desde una lógica que tiene en cuenta

Toda "materia de conocimiento", y los problemas que debía plantear en su sentido más amplio (ni siquiera concebido con claridad, por cierto); una lógica que sí toma en cuenta esa materia: problemas tales como la posibilidad de un conocimiento de la realidad efectiva o la conformación de las verdades sobre el mundo real (Husserl, 2009 [2], p.122).

El giro epistemológico aquí implícito requiere analizar los procesos en la construcción del conocimiento, dando cuenta, al mismo tiempo, de las condiciones históricas que hicieron posible que ese conocimiento se formara como tal, es decir, desvelando qué modo de producir la realidad le antecedió. Este giro da lugar a nuevas áreas de conocimiento, al tiempo que sienta las condiciones para la formulación de nuevos problemas de investigación ${ }^{3}$. En esta reflexión, entendemos la ruptura epistemológica como una vía desnaturalizadora de los procesos de conocimiento, con una complejidad analítica que deja de trabajar desde una epistemología naturalista, y apunta a una constructivista.

Ahora bien, la dimensión constructivista en el campo de la visualidad supera el viejo dilema sujeto-objeto, no solo por la presencia de aquellos especialísimos momentos, ya descritos antes, en los que el sujeto cae en el lugar del objeto cuando lo real tras la realidad le devuelve la mirada (angustia), sino también por la configuración de una noción de objeto más orgánica y sistémica. En esta línea argumentativa, los objetos son entendidos como "Elementos complejos, que es erróneo tratar de simplificar, sino que, además, son

3 A lo largo de la historia, diversas rupturas epistemológicas han ido desgarrando las fronteras previas del conocimiento y se han ido inscribiendo en nuevas lógicas de la producción del sentido: entre ellas, el materialismo histórico, la fenomenología, el pragmatismo, la hermenéutica, el psicoanálisis, los sistemas complejos y la psicogenética, entre otros, han ido posibilitando salir de la forma naturalista y de sistemas cerrados de la ciencia. En esta medida, cuando logramos una analítica de la realidad, no desde naturalezas como esencias fijas de significado, sino como procesos de construcción en permanente movimiento, ya estamos pensando en la complejidad de las formaciones del conocimiento. Estas formaciones posibilitan la instauración de una lógica del sentido en la que participan los sujetos, los objetos y los sistemas socioculturales, interactuando en un espacio y en un tiempo determinados. En la medida en que dicha lógica se sostenga, ese espacio adquiere ritmo y movimiento, es decir, tiene sentido; esto es: cobra realidad. Conforme a que las interacciones entre dichos sujetos, sistemas socioculturales, objetos, tiempos y espacios van aumentando, al ligual que las existentes entre las experiencias previas a ellos, la visibilidad de las realidades se complejiza y el ojo empieza a percibir aún más vínculos. 
elementos despojados de una unidad natural en su complejidad, no comparables con un cuerpo químico simple ni tampoco con una combinación química" (Saussure, 2004, p. 24).

Desde esta perspectiva, la percepción ya no es percepción de los objetos naturales, sino también de entidades simbólicas, lo cual obedece a que

El mundo natural, que es también el objeto de estudio de las ciencias de la actitud natural, no es sólo un mero «mundo de cosas, sino, en la misma forma inmediata, un mundo de valores y de bienes, un mundo práctico. Es estando en actitud natural cuando se tiene «ahí delante»el mundo natural entero que no se reduce a ser un mero mundo de objetos; es también un mundo en el que se presentan caracteres de valor y caracteres prácticos (Padilla, 2006, p. 89).

Cuando nos referimos a un agotamiento del naturalismo epistemológico, asumimos no solo que el mundo de cosas, es decir, lo inmediato que se nos presenta ante nuestros sentidos posee una carga más compleja que la puramente designada por lo natural (como hemos señalado reiterativamente en este texto), sino también que no únicamente se observa y se mira con los ojos. Al participar del mirar, los objetos del mundo se nos revelan visibles, pero también escrutadores, visibilizadores de un sujeto sorprendido, incluso fascinado ${ }^{4}$ ante el proceso complejo que antecede a la visibilidad como tal.

La visibilidad y su complejidad se presentan, en esta vía, precisamente como uno de esos nuevos problemas inaugurados por la epistemología luego del agotamiento del naturalismo. Ya Freud había señalado que el pensamiento visual se halla más emparentado con los procesos inconscientes, y que es más primigenio que el pensamiento verbal, tanto en términos del individuo, como de la especie. En el ámbito de este pensamiento,

[...] solo se hace consciente el material concreto de las ideas, y, en cambio, no puede darse expresión alguna visual a las relaciones que las caracterizan especialmente. No constituye, pues, sino un acceso muy imperfecto a la conciencia, se halla más cerca de los procesos inconscientes que el pensamiento verbal, y es, sin duda, más antiguo que éste, tanto ontogénica como filogenéticamente (Freud, 2003, p.15).

El pensamiento visual contemporáneo, por su parte, detecta el nivel del imaginario al mismo tiempo que desvela al régimen escópico que lo sostiene, acudiendo a la pregunta por cómo se construye la realidad a partir de haberla visto, y de cómo, simultáneamente, se ve la realidad a través del filtro de las construcciones que los sujetos hacen con respecto a ella. Estos dos cuestionamientos, o más bien, este cuestionamiento "de doble filo", subsume los asuntos de la visibilidad, el imaginario y los regímenes escópicos, trasladando la atención hacia nuevos enfoques epistemológicos, como por ejemplo las epistemologías transculturales de la visualidad, especialmente aquellas que "toman en cuenta la autorreflexi-

4 El término fascinum se usa originalmente para referirse al encantamiento en sí, pero con el transcurrir del tiempo designó solo el "mal de ojo". Luego, se empleó para referirse al tipo de amuletos concebidos para conjurar tal peligro (Galve, 1983, citado por Saénz y Lasuén, 2004). San Agustín usa el término en las Confesiones para aludir al pendiente fálico que solía colgarse al cuello de los niños y ser usado por las mujeres como adorno (San Agustín, citado por Sáenz y Lasuén, 2004). 
vidad de las etnografías críticas, pero desde la óptica de la crítica geoepistemológica al ocularcentrismo normativo" (Barriendos, 2011, p. 24). Este paradigma epistemológico considera a la visibilidad como campo de conocimiento contemporáneo, que permite pensar, desde un constructivismo epistemológico y desde una analítica de la complejidad, en la percepción de la realidad. En el ámbito de este paradigma, imaginario y régimen escópico se convierten en ejes para analizar el Pensamiento Visual Contemporáneo y sus trans-formaciones.

\section{La construcción de la visibilidad desde un régimen imaginario}

La epistemología (visual), en su función de analizar los fundamentos, se pregunta sobre la formación de la visibilidad, la génesis de las cosas, sus orígenes, la caracterización de sus formaciones:

La visualidad comprende, entonces, el desciframiento, la decodificación y la interpretación de la experiencia visual a través de variables propias, algunas heredadas del modelo textual y otras proporcionadas por sus indicadores específicos. De este modo, estamos inmersos en una iconósfera, ya que las imágenes determinan el modo de percibir, interpretar y pensar el mundo. La comunicación visual es, por tanto, una construcción de sentido interactiva y cultural (Niedermaier, 2013, p. 34).

La pregunta por los orígenes de la visibilidad y el imaginario remite, a su vez, a la pregunta por la génesis de la visibilidad desde la semiótica5: la semiótica en el ámbito del análisis complejo en la construcción de la visualidad. ¿Qué proceso complejo se juega cuando hablamos de visibilizar algo, de percibir la realidad? Para ver, necesitamos un imaginario previo que posibilite la coordinación de los objetos con los ojos, de tal manera que la percepción los transforme en señales para la vista y la mirada.

\section{a. Imaginario}

El término imaginario ${ }^{6}$ inicialmente lo extraemos del debate psicogenético sobre cómo se van formando las percepciones; el constructivismo piagetiano sostiene la presencia de procesos sucesivos y reversibles entre experiencias previas que se inscriben en el cuerpo. Estas experiencias son producidas por el cuerpo como imágenes mentales, que luego serán la base de la representación conceptual, de la visualidad ${ }^{7}$.

5 El estudio del conocimiento desde una epistemología, abre el debate de la semiótica contemporánea; por semiótica concibamos los estudios visuales desde la complejidad que implica el proceso cognitivo del conocimiento, que inicia desde la percepción misma del objeto.

6 "Las imágenes se sitúan pues en los pliegues de lo simbólico y lo real, de lo conceptual y lo existente, de lo mágico y lo existencial. A pesar de que la capacidad movilizadora de las imágenes se registra desde la Antigüedad, se puede afirmar que en la contemporaneidad esta facultad se ha ido incrementando" (Niedermaier, 2013: 36).

$7 \quad$ A este proceso de inscripción de las experiencias y de formación de conocimiento en el cuerpo humano lo llamamos "la función semiótica", noción que no solo encontramos en Lev Vygotski, sino también en Jean Piaget, como la capacidad de dotar de sentido a los objetos. Es interesante la correspondencia que encontramos, desde esta función, entre percepción e inteligencia. 
Ahora bien, en el rastreo histórico del estudio de la percepción como proceso psicológico sobre el cual descansa la formación de imágenes, la reversibilidad piagetiana constituye solo un paso en el largo camino de la complejización de lo visual, hasta llegar a la consideración del carácter háptico del campo escópico:

[...] el asunto de la imagen se propone como ámbito complejo, no desde la preeminencia de las imágenes, sino en la actualidad por su condición háptica, es decir, por su potencia para involucrar todos los sentidos y la apertura a otros niveles de "conocimiento" del mundo (descripción de la composición de las relaciones que nos-co-constituyen), con lo cual, lo visual deviene tacto, olfato, palabra, gesto, sabor, sonido, pensamiento (Rodríguez, 2011: 67).

En este camino histórico de complejización, la explicación constructivista en el proceso de formación de imágenes e imaginarios, sostiene que lo central en tal proceso es la interacción entre el objeto, el sujeto y un contexto, y las imbricaciones entre las dimensiones real, imaginaria y simbólica que de tal interacción surgen:

Tales imaginarios son constructos históricos, realidades construidas mediante procesos de interacción social; en esos procesos tienen un papel fundamental en las relaciones de poder, obviamente (poder político, empresarial, sindical, académico, etc.). Un imaginario no es necesariamente material: es una realidad imaginada -real-contingente a la imaginación de un sujeto social concreto. Por supuesto, hay diversas visiones sobre el estatus ontológico del imaginario colectivo. Algunos autores entienden que el imaginario es harto real, mientras que otros le atribuyen un carácter real imaginado (Anonymous, 2013, p. 433).

La materialidad del imaginario es resultado de la coordinación abstracta de las imágenes que el cuerpo ha experimentado, y a partir de la cual se produce pensamiento conceptual -inteligencia-. Esta coordinación es la que, en últimas, le permite al sujeto mirar, percibir ${ }^{8}$. El carácter imaginado del imaginario, antes que falsedad, desvela el alto contenido de ficción de la percepción y del propio régimen escópico. En este sentido, lo ficcional se presenta, no como "mentira", sino justamente como el lugar de lo simbólico, del Otro como portador de la palabra:

Por eso era tan útil que planteara en las primeras fases de este discurso sobre la angustia la distinción esencial de estos dos registros: por una parte, el mundo, el lugar donde lo real se precipita y, por otra parte, la escena del Otro, donde el hombre como sujeto tiene que constituirse, ocupar su lugar como portador de la palabra, pero no puede ser su portador sino en una estructura que, por más verídica que se presente, es estructura de ficción (Lacan, 2006, p. 129).

8 Entonces, la inteligencia humana ha dejado de ser -nunca fue-una comprobación de respuestas visuales y se ha desplazado hacia la complejidad entre los diferentes registros del cuerpo: entendemos, por consiguiente, que los ojos no ven por sí solos, sino que la visión es una formación compleja que consiste en el apoyo o soporte que le ofrecen los demás registros del cuerpo a los ojos; así, no vemos con los ojos, sino que percibimos con conceptos, y tal "percepción conceptual" es resultado de la coordinación compleja entre las diferentes imágenes del cuerpo. 
La génesis de la inteligencia está implícita en la función semiótica, dado que "esta permite presentar objetos o acontecimientos no actualmente perceptibles evocándolos por medio de símbolos o signos diferenciados" (Piaget; 2005, p. 41); ahora bien, como capacidad de dotar de sentido a los objetos desde la coordinación de las imágenes, tal función no se agota ahî́. Repensar el origen de la visualidad nos permite formular concienzudamente la pregunta sobre el origen de las imágenes mismas. La teoría de la coordinación de las imágenes, propuesta desde el constructivismo, nos sirve para entender cómo vamos estructurando algo así como una percepción de un objeto, o dotando de sentido al mundo, o cómo producimos una representación.

Sin embargo, es necesario no perder de vista que, aunque la capacidad coordinadora de las imágenes propia de la función semiótica es fundamental para el desarrollo de la inteligencia, las imágenes como tal provienen inicialmente del cuerpo incoordinado. Sobre esta incoordinación, penoso origen de las imágenes, se ha pronunciado el psicoanálisis, epistemología rupturista con respecto al método científico, avanzando sobre el conocimiento complejo de las imágenes como resultado de la coordinación del cuerpo que señala el constructivismo.

Lo que el psicoanálisis nos ofrece es un análisis de la visualidad, al ubicar la imagen como objeto de estudio. La teoría lacaniana de la imagen expone que esta proviene de ese lugar donde el cuerpo aún no posee una coordinación física, ni mucho menos abstracta; la imagen sería producto de la organización precipitada, anticipada, de un cuerpo que aún no puede mantenerse en pie. Esta coordinación anticipada desde la insuficiencia, parte de un conjunto de imágenes fragmentarias, de experiencias lagunosas y quebradas que, no obstante, ofrecen, en un momento temprano del desarrollo, una de las primeras ilusiones de dominio sobre el cuerpo:

El estadio del espejo es un drama cuyo empuje interno se precipita de la insuficiencia a la anticipación; y que para el sujeto, presa de la ilusión de la identificación espacial, maquina las fantasías que se sucederán desde una imagen fragmentada del cuerpo hasta una forma que llamaremos ortopédica de su totalidad -y a la armadura por fin asumida de una identidad enajenante, que va a marcar con su estructura rígida todo su desarrollo mental (Lacan, 2005 [1], p. 90).

El espejo necesario para que tal prodigio tenga lugar, para que dicha coordinación ilusoria sea posible, es un otro ratifcante, primer Otro del infans y también primer elemento enajenante, externo (y terriblemente interno, por lo cual Lacan acuña el término éxtimo) de su existencia. Esta ratificación jubilosa es la contraparte de lo unheimlich, de lo siniestro como momento en que el espejo se rompe y desvela lo que hay detrás: la fragmentación y la intromisión de algo ajeno que sostenía subrepticiamente la imagen, y que se hizo

9 La función semiótica podría resumirse así: el sujeto, vía la interacción con sistemas socioculturales abstractos, genera experiencias previas y las coordina con las nuevas. Tales coordinaciones se traducen en esquemas cognitivos que a su vez se trnsforman en conceptos que estructuran la percepción del sujeto, y que al estar en permanente construcción, pueden ensancharse o modificarse. La investigación a detalle del funcionamiento de dicho proceso cognitivo, es el objeto de la psicogenética constructivista. 
visible. Esta ruptura es una suerte de "despertar" súbito, parecido paradójicamente al sueño áurico que anuncia, según Steiner, la epilepsia:

En las primeras etapas de la epilepsia se presenta un sueño característico (Dostoievski habla de ello). De alguna forma nos sentimos liberados del propio cuerpo; al mirar hacia atrás, nos vemos y sentimos un terror súbito, enloquecedor: otra presencia está introduciéndose en nuestra persona y no hay camino de vuelta (Steiner, 2003, p. 32).

No obstante, es necesario que "permanezcamos dormidos" para salvaguardar nuestra identidad, nuestra integridad yoica. La mirada es la antípoda escópica de la vista y surge en el momento siniestro del despertar; en cambio, la visualidad se organiza, desde su origen, alrededor de imágenes ortopédicas que mantienen todo en orden para cubrir esa fragmentación y hacerla parecer otra cosa casi totalmente opuesta, manteniendo así el sueño, la pantalla de la realidad. La imagen es, entonces, ilusoria en tanto una fragmentación subyace a ella.

En la "Agresividad en psicoanálisis" Lacan (2005 [1]) plantea esta complejidad (llamada estadio del espejo) que nos permite analizar el problema de la visualidad desde la sociogénesis de la imagen; es decir, no solo nos revela el problema de la coordinación de las imágenes, sino, además, esa zona de fragmentación, de no coordinación. La teoría lacaniana no retrocede y detecta que ese lugar de la imagen fragmentada es el lugar de la huella mnémica como noción ineludiblemente ligada al lugar del otro:

El estadio del espejo tiene el interés de manifestar el dinamismo afectivo por el que el sujeto se identifica primordialmente con la Gestalt visual de su propio cuerpo es, con relación a la incoordinación todavía muy profunda de su propia motricidad, unidad ideal, imago salvadora; es valorizada con toda la desolación original, ligada a la discordancia intraorgánica y relacional de la cría de hombre, durante los seis primeros meses, en los que lleva los signos, neurológicos y humorales, de una prematuración natal fisiológica" (Lacan, 2005 [1], p. 105).

El pasaje al otro/Otro inicia desde la identificación de la imagen del cuerpo en el espejo, imagen que va de la incoordinación y la discondarcia intraorgánica, hasta la formación de signos, de coordinaciones que devienen en visibilidad y en lenguaje. El otro/ Otro nutre el imaginario desde el cual miramos y lo dota de sentido (simbólico) ilusorio ${ }^{10}$, pero también se presenta como potencial doble ominoso, como imagen que escapa del espejo y aparece donde no debería estar: acechando, invadiendo el espacio subjetivo.

10 Sin embargo, "ilusorio" no es sinónimo de "falso": la organización de la visualidad alrededor de la ilusión es necesaria para la formación del yo y para el mantenimiento de la unidad de la conciencia; no conocemos otro modo de visualidad posible. Si viviésemos conscientes de nuestra fragmentación, o visualizando presencias donde no deberían estar (ese algo en el lugar de la falta al que se refiere Lacan en la explicación de lo unheimlich, lo ominoso) seguramente terminaríamos todos psicotizados (lo que abre el interesante debate sobre la visualidad -en sentido amplio- en la locura y su relación con la verdad). El imaginario es una colección de imágenes inscritas en el cuerpo y de experiencias sensoriales que se coordinan desde la incoordinación para dotar de base material a la realidad, realidad sostenida sobre una cierta forma de ver el mundo, desde una visibilidad que, por su mismo carácter imaginario, puede todo el tiempo devenir otra cosa. 
Este lugar situado en el Otro

[...] representa la ausencia en la que nos encontramos. Suponiendo, como a veces ocurre, que ella se revele como lo que es - o sea, que se revele la presencia en otra parte que constituye a este lugar como ausencia- entonces ella manda en el juego, se apodera de la imagen que la soporta, y la imagen especular se convierte en la imagen del doble, con lo que ésta aporta de extrañeza radical. Por emplear términos que adquieren su significación por oponerse a los términos hegelianos -hace que aparezcamos como objeto, al revelarnos la no autonomía del sujeto (Lacan, 2006, p. 58).

El problema de la imagen no empieza en la fragmentación de las primeras imágenes en el cuerpo, sino justamente en el otro que las produce, pues la imagen solo es imagen de algo o de alguien, imagen del otro; todo ya estaba en el otro antes del yo: "Del espacio detrás del espejo [...] dar una imagen de cómo la relación con el espejo, o sea, la relación imaginaria con el otro y la captura del Yo Ideal sirven para arrastrar al sujeto al campo donde se hipostasía en el Ideal del Yo" (Lacan, 2005 [2], p. 659). Es decir, el espejo es el constante reflejo o interacción imaginaria que tenemos con el otro, pero también le da consistencia real y le otorga materialidad a Otro simbólico (terreno del Ideal del Yo); el espejo es la reiteración, no únicamente de que la imagen está en perpetuo movimiento por la interacción con el otro, sino además de que, antes de que la realidad esté dada por un mundo natural, está contenida en el Otro, está atravesada por el significante, por el lenguaje.

El otro (y en última instancia, el Otro) se instauran como garantes de producción de imágenes, pero también como portadores ominosos del acecho de una incoordinación que se experimenta como ajena (cuando ciertamente es lo más propio, lo más íntimo, lo más constituyente), lo cual inaugura un espacio imaginario de relaciones con algo que no es uno y que no permite una visualidad pura ("en qué estará pensado" se pregunta el otro, y también el uno, pues el uno es el otro), como señalando hacia una suerte de intencionalidad alienante, proveniente de algo que nunca estuvo dentro del sujeto, que ineludiblemente es social.

En este sentido de la intencionalidad, todo naturalismo abstracto alejado de la formación de la imagen queda puesto en entredicho, puesto que desconoce los

$[\ldots]$ horizontes intencionales [...] el sentido del ser de los objetos, de las formaciones teóricas, de los valores, los fines [...] determinan el sentido de su esfera de objetos [...] tienen horizontes intencionales indeterminados, son formaciones de obras intencionales desconocidas, practicadas sólo en tosca ingenuidad. Eso no sólo vale para las ciencias positivas especiales, sino también para la lógica tradicional con todas sus normales formales. Todo intento por llegar, a partir de las ciencias históricamente desarrolladas, a una mejor fundamentación, a una mejor comprensión de sí mismas por lo que hace a su sentido y a su obra, es un fragmento del autoexamen del científico. Hay empero solamente un autoexamen radical, esto es, el fenomenológico (Husserl, 2009 [1], pp. 36 y 37).

Las formaciones teóricas que sugiere la fenomenología atraviesan ese camino complejo posibilitado por el otro; en este orden discursivo, la imagen permite pensar 
una realidad construida desde formaciones de sentido previo, cimentadas en el otro (y el Otro) como reguladores de una carga histórica que coordina las imágenes para hacer ver, de cierta forma, algo así como una realidad. El autoexamen al que apunta Husserl es el reconocimiento de ese otro/Otro que produce las imágenes e inscribe los significantes en el cuerpo, y que al mismo tiempo deja un espacio abierto que nunca llega a ser totalizable: una analítica del sentido y de las condiciones que hacen pensar cómo se construye la realidad.

Entonces, la visualidad desde el imaginario nos permite entender la percepción y la mirada como una imagen del mundo (un "qué vemos", en sentido complejo) ya "contaminada", imagen que plantea que no hay percepción natural o pura del mundo, sino que el mundo, en su faceta más crudamente real, también se sostiene por imágenes del mundo. Estas imágenes, aportadas por esa imbricación imaginario-simbólica que daremos en llamar Lo otro, se producen en el cuerpo, para recoger la reflexión que hicimos antes, como experiencias que se coordinan en términos de la mediación semiótica, en el ámbito de lo fenoménico:

El vivir psíquico mismo sólo se hace patente en la reflexión. A través de ella aprendemos, en vez de las cosas puras y simples, en vez de los valores, los fines, los útiles puros y simples, las vivencias subjetivas correspondientes en las cuales llegan a ser para nosotros «conscientes», en las cuales, en un sentido amplísimo se nos «aparecen». De ahí que todas estas vivencias se llamen también «fenómenos»; su característica esencial más general es ser como «consciencia-de» o «apariciónde»-de las respectivas cosas, pensamientos (juicios, razones, consecuencias), de los planes, decisiones, esperanzas, etc. Por ello en el sentido de todas las expresiones para vivencias psíquicas de los lenguajes populares se encierra esta relatividad: acordarse de algo, pensar en algo, percibir, esperar o temer algo, aspirar a algo, decidirse por algo, etc. Si este reino de los «fenómenos» se muestra como un campo posible de una disciplina psicológica pura, exclusivamente referida a ellos, resulta comprensible que esta última se caracterice como una psicología fenomenológica (Husserl, 1998, p. 38).

Nuestra visibilidad está atravesada por (in)coordinaciones de imágenes del otro en constante actualización, movimiento y distorsión. Así, la realidad se nos presenta como resultado de la interacción de lo propio con lo ajeno, del nosotros que no es simplemente yo más otros, plano de fenómenos (entendidos como imágenes del mundo que al asociarse producen visibilidad) constructor de la realidad.

\section{b. Régimen escópico}

La realidad como construcción implica en términos teóricos el análisis del proceso visual en sentido complejo; por ello, detectamos el espacio de formación de imágenes, zona donde las imágenes se coordinan prematuramente y en la que se actualiza como tal la percepción del objeto (del otro) en la interacción: la realidad como imaginario.

Esta zona de formación queda abierta y, más que alejada de la representación y de los conceptos, es previa a la representación, o, por decirlo de otra manera, es la base de toda conceptualización. Esta zona-imaginario presenta características interesantes, 
porque ofrece imágenes coherentes, pero en el fondo es real y está fragmentada: es quizá lo más real del cuerpo, lo más suyo, pero al mismo tiempo, lo más distorsionado, lo menos "acabado". Tal inacabamiento obedece precisamente a la dimensión real que escapa a toda escena imaginaria y a toda regulación simbólica, y que permanece indómita aún tras el marco del espejo.

Se trata de un lugar donde las imágenes están saturadas de afectos parciales, por llamarlo de alguna manera acorde con la parcialidad de la pulsión. Esta caracterización freudiana de los afectos escapa, sin embargo, a la perspectiva psicoanalítica tradicional de la maduración como integración, lo cual implica que tales afectos no están pendientes de construcción; por el contrario, esta zona, algo caótica, lucha contra los afectos que el cuerpo deposita en las imágenes que se forman tras la coordinación precipitada a la que nos hemos referido antes. Las imágenes están fragmentadas desde que provienen del otro: en último término, ese Otro que es garante, sostén para invisibilizar la fragmentación y permitir la configuración de imágenes al otorgarles registro y proponer una ley y un marco desde lo simbólico, desde el cual se ve la realidad.

Esta perspectiva integradora (esta vez en términos transdisciplinares) nos permite considerar la dimensión de lo visual como posible objeto de estudio, con la consecuente pertinencia del campo de los estudios visuales. Tal perspectiva se compromete con el imaginario, la zona de imágenes desde donde se construye la visibilidad a partir de una suerte de coordinaciones de lo incoordinado, pero también de incoordinaciones súbitas, siniestras, de lo coordinado. Por otro lado, la complejidad de la realidad no se detiene ahí, sino que apunta hacia el análisis de la formación de las imágenes y la identificación de que están construidas por el otro-prójimo, y que es el Otro-cultura el que posibilita esa forma de mirar, ese acto de ver, de vérnoslas con el mundo, de enfrentarnos con éll".

Desde el momento mismo en que el acto de ver es concebido como ligado al Otro, esta ligazón tiene que ver con los regímenes escópicos, entendidos como dispositivos complejos de visualidad.

Hemos apuntado que la visibilidad tiene un componente imaginario, esto es, un plano desde al cual los objetos, antes que objetos son imágenes, o dicho de otra forma: el objeto cobra sentido en la percepción a través de esa forma particular de coordinación que es una imagen. También hemos señalado que el origen de todo imaginario no está

11 No en vano hemos empleado esta expresión guerrerista, pues consideramos que vérselas con el mundo, ver el mundo, implica ya una tensión, un enfrentamiento metafóricamente cruento, que sigue la lógica de una suerte de pulsión de muerte que plantea el debate entre la perpetuación del orden y la aparición de algo nuevo. "En el plano psicoanalítico, la pulsión de muerte es inherente al hombre: es una lucha obstinada, continua e inexorable que lo empuja a buscar paz y distensión por cualquier medio, bajo cualquier forma, y no solamente una fuerza que tendería a transformar lo animado en inanimado" (Rechardt, 1998, p. 53). La formación de las imágenes de la realidad tiene lugar en una zona de violencia, de resistencia y rechazo a la cultura, a esos elementos que, tras un análisis detallado, devienen enajenantes. Todo esto sucede como si la civilización tuviera un alto costo: la alienación a las formas de ver que el Otro plantea como la realidad. Frente a tal alienación, surge la creatividad radical (Castoriadis) como forma de escapar a lo que del Otro hay en nosotros. 
en las imágenes, ni siquiera dentro de los cuerpos, sino que el imaginario se encuentra afuera del cuerpo, en el mundo dispuesto alrededor, y que solo después se inscribe en el cuerpo. Esta exterioridad inicial del imaginario puede expresarse en términos de las significaciones previas, de la experiencia originaria, la cual

Supone que, a ras de la experiencia, antes incluso de que haya podido retomarse en la forma de un cogito, hay significaciones previas, ya dichas de alguna manera, que recorrían el mundo, lo disponían a nuestro alrededor y daban acceso desde el comienzo a una especie de primitivo reconocimiento (Foucault, 2009, p. 48).

Además, afirmamos que las imágenes entran en sistemas complejos de coordinación previa -y prematura- del cuerpo, lo que producirá una realidad, una realidad que no está en un otro-prójimo concreto (mi madre, mi padre, tal amigo, tal personaje de la televisión), sino en el Otro entendido como garante de una forma de ver construida históricamente y atravesada por el símbolo y sus leyes: "El hombre encuentra su casa en un punto situado en el Otro, más allá de la imagen de la que estamos hechos" (Lacan, 2006, p. 58). Lo epistemológico de la mirada no reside en los ojos, sino en la complejidad con la que dotamos a la vista. Eso es lo que el régimen escópico, entendido como Otro, como dispositivo de visibilidad, vigila y protege: que ciertos actos de ver, ciertas formas de visibilizar el mundo, se produzcan desde sus certezas y límites ${ }^{12}$.

De esta manera, resulta un espacio más que ya no queda en el cuerpo, que supera al sujeto, y con relación al cual, sin embargo, no es suficiente una teoría del objeto: "En el hombre, cuya adaptación al medio se modifica por completo, destaca en primer lugar el desarrollo de sus órganos artificiales -las herramientas- y no el cambio de sus propios órganos ni la estructura de su cuerpo" (Vygotski, 2000, p. 31). Este espacio, el espacio escópico, es un régimen virtual que hace que los sujetos vean de cierta manera a los objetos, considerados estos como herramientas en términos vygotskianos, que ya poseen una carga histórica de sentido. Esta carga ha sido forjada al calor de ese complejo proceso de construcción de la realidad, que hemos propuesto como puesta en acción de los cuerpos en interacción, bajo un marco de sentido que los antecede y los hace ver de cierta forma.

El régimen escópico se relaciona, por consiguiente, con las formulaciones históricas de sentido que disponen la coordinación de imágenes, imágenes que devienen en representación: "Diríase que el desarrollo cultural se separa de la historia, como si se tratase de un proceso independiente, autosuficiente, regido por fuerzas internas existentes en el mismo, supeditado a su lógica inmanente. El desarrollo cultural se considera como autodesarrollo" (Vygotski, 2000, p. 22). Así como la epistemología visual ubica una zona de formación previa a la representación en las coordinaciones de imágenes del cuerpo, ubica también una zona de formaciones socioculturales de dicha representación. Esta

12 Una producción de visibilidad tiene que ver con trazar límites entre lo que es realidad y lo que no -lo verdadero y lo falso-; asimismo, no solo se trata de delimitar fronteras, sino también de identificar certezas: la pregunta aquí no solo es hasta dónde algo es válido, sino además cuál es la certeza que valida ese algo; desde semejante perspectiva, lo inválido del discurso psicótico contrasta con la certeza del discurso del psiquiatra. 
otra zona es donde reside el régimen escópico, como eso que antecede a la percepción y que coordina las imágenes haciendo de la representación, antes que algo psicológico, algo histórico ${ }^{13}$.

¿Cómo podemos acceder a esa zona que llamamos régimen escópico, para, asimismo, entrar en contacto con las formaciones de la representación que en su complejidad nos revela el proceso histórico-psicológico? Accedemos al régimen escópico mediante las formaciones discursivas, lo cual viene a reafirmar la imbricación última entre lo imaginario y lo simbólico. En este ámbito discusivo, los especialistas discuten sobre el asunto de la novedad conceptual: ¿es posible una innovación del lenguaje que establezca cierto tipo de visión "inédita" del mundo, o el mundo siempre es el mismo porque las combinaciones lingüísticas (no solo entre palabras, sino también entre cargas valorativas e históricas de las mismas) son, de suyo, limitadas?

En correspondencia con este ámbito de lo discursivo, y tal como hemos venido sospechando, no hay mirada que pueda darse en estado natural. Toda mirada emerge de una red de enunciados y conceptos que la modelan, la configuran y conducen su disposición: esta red es el a priori histórico (formulación un tanto desafortunada según Foucault), que hace referencia a una estructura discursiva anterior al sujeto-observante, que marca un límite en la conjunción y la formación de los enunciados.

Por a priori, dice Foucault, "Entiendo una condición de realidad para unos enunciados, la ley de su coexistencia con otros, la forma específica de su modo de ser, principios según los cuales subsisten, se transforman y desaparecen" (Foucault, 2001, pp. 215-216). Todo lo que puede decirse o verse surge desde dicha posibilidad discursiva; nada puede agregarse a la percepción y la enunciación si dicha regularidad lo excluye. Así, quien observa, describe o señala lo hace desde una formación discursiva que lo antecede y lo constituye.

La posibilidad de generar enunciados, conceptos y, por ende, discursos novedosos es una emergencia originada desde tal a priori. Es decir, el entramado discursivo sobre el que reposa el sujeto cognoscente lo condiciona y lo limita, y al mismo tiempo, le abre un acceso a aquellas nuevas formas discursivas emergentes. Sin embargo, es siempre desde tal red discursiva previa, nunca sin ella, y menos aún desde fuera de ella, que tienen lugar tales discursos "creativos", pues, antes que el sujeto (sujetado), están

[...] las reglas de construcción de [los saberes] en una época dada, como si, antes que, por una voluntad consciente de racionalización, se sostuviesen en un sistema anónimo de reglas vigentes sobre el conjunto de saberes de una época. Rápidamente se comprobó, pues, que Foucault, en su exposición histórica de los saberes, no describía tantos momentos de afirmación soberana y libre (al menos, liberadora) de la razón, sino, por el contrario, una sujeción generalizada del pensamiento a sistemas arbitrarios de reglas (Gros, 2007, p. 57).

13 Dar cuenta de la complejidad que implica abordar el problema de la construcción del espacio desde niveles de sentido, analizando el proceso cognitivo en la construcción del espacio, nos abre un tercer tiempo: sujeto-objeto y espacio. 
Esta red virtual, materia de la que parte el régimen escópico, se materializa en los saberes elevados como discursos que producen los límites entre certeza y falsedad. El discurso se manifiesta como a priori de verdad; en este orden, los discursos y los regímenes escópicos resultantes no son libres, en el sentido que no liberan, ni tampoco están hechos por una única fuerza o verdad, sino que son el gesto productivo, el resultado de toda una época histórica. Esto explica por qué tenemos la impresión que en esta época los regímenes escópicos han superado a los regímenes discursivos mismos, lo que conduce a autores como José Luis Brea a decir que

[...] la imagen de hecho ha desbordado al relato en su potencia simbólica de inducción de formaciones de comunidad. Las nuevas comunidades ya no se constituyen tanto en la adhesión fidelizada a una narrativa específica, que hacen objeto de su fe compartida, sino sobre todo en la relación puntual y dinámica con una constelación de imágenes en circulación con las que se produce una relación de identificación y reconocimiento que poco a poco las va sedimentando como memoria compartida, imaginario colectivo (Brea, 2007, p. 159).

No creemos que sea esta una época en la que lo escópico desborde particularmente lo discursivo; lo que sí sostenemos, es que la visualidad misma de lo escópico ha aumentado por la proliferación explícita de las imágenes; no obstante, esta hipervisualización de lo visual, valga la redundancia, es también un efecto discursivo; ejemplo de ello es que posturas como la de Brea son cada vez más frecuentes. En todo caso, durante toda la historia, a excepción de periodos y culturas específicas, las imágenes circulantes han sido tan fundantes de la realidad, como las palabras circulantes.

Tanto las imágenes en el cuerpo, como el espacio escópico, se materializan como virtualidad, entendida como "algo que sin ser real produce el mismo efecto que si lo fuera". (Biosca, 2009, p. 35). Esta definición, procedente de la filosofía aristotélico-tomista, indica que lo virtual no es propiamente irreal ni mucho menos invisible; para la reflexión que aquí nos convoca, lo virtual adquiere consistencia en el cuerpo, produciendo en él efectos y conceptos y traduciéndose en prácticas cotidianas. Se refiere a todo eso que no se ve con los ojos, pero sin lo cual no verían los ojos ${ }^{14}$ (Bergson, 2006). La materialidad de lo virtual pasa por las imágenes que coordina el cuerpo desde el Otro, ese "extraño sujeto que no es simplemente otro ser humano, sino un Tercero, un sujeto que se ubica por encima de la interacción de los individuos" (Zizek, 2008, p. 50).

Cuando decimos que la realidad no es algo dado o natural, sino que implica toda una complejidad en el proceso de su construcción, nos atenemos a las anécdotas de la historia de la ciencia, como aquella que nos propone Dreyfus: "Imaginemos lo que sintieron los que vieron por primera vez seres diminutos que habían pasado inadvertidos

14 Lo virtual es un nivel no concreto que resulta de la coordinación entre los diferentes accesos perceptivos del cuerpo; por ello, la función semiótica no solo entiende lo visual como el resultado de la interacción entre objetos y coordinaciones previas del cuerpo, acto que sucede en simultáneo ocasionando desfases, desequilibrios entre de las coordinaciones previas del cuerpo y la variación de los objetos actualizándose por efectos de interacción-; la función semiótica trabaja ahí en lo virtual, en eso no accesible a los ojos pero con el que se puede ver, plano de la imagen en el que se sostiene la percepción. 
bajo sus microscopios" (Dreyfus, 2009, p. 13). Cuando el ser humano logró ver más allá del límite de su capacidad ocular gracias a herramientas cognitivas como el microscopio, podemos entender que fueron las herramientas socioculturales las que hicieron ver al científico, y no sus ojos.

En este sentido, los ojos miran a través de lentes históricos que dotan de condiciones de posibilidad a la mirada, que establecen actos de ver. Nuestra mirada está circunscrita por las herramientas socioculturales a la mano, y por las imágenes previas que tenemos del mundo, mundo que se nos revela como realidad a la que habrá que adaptarse la vista. Se trata esta de una suerte de adaptación escópica a cierta forma de mirar, que nos instala en una realidad que necesita producción de trabajo y una cotidianidad controlable para articularse ${ }^{15}$.

Esta cotidianidad, cultivada a partir de prácticas tanto del yo como del otro, está cargada de una lógica y de una complejidad que suelen obviarse, justamente por su carácter usual, habitual ${ }^{16}$. Atendiendo a la necesidad de hacer retroceder esta simplificación, el estudio de esta zona virtual se propone, no como observación, sino como intento de visibilización de niveles de complejidad en la construcción de la realidad.

A la simplificación de la vida cotidiana, el régimen escópico contribuye al hacer ver de cierta forma las cosas, o, dicho de otra manera, al hacer dejar de ver ciertas cosas. Pero los regímenes escópicos no solo regulan la vida cotidiana, también normativizan las formas hegemónicas de ver de otros espacios, supuestamente menos cotidianos; tal es el caso de la construcción de las entidades nosológicas y de su despliegue en un conjunto validado de prácticas del ver, que, a su vez, decantó en intervenciones presumiblemente terapéuticas, pero cuyo fin último descansaba sobre el control:

El espacio de configuración de la enfermedad y el espacio de localización del mal en el cuerpo no han sido superpuestos, en la experiencia médica, sino durante un corto período: el que coincide con la medicina del siglo XIX y los privilegios concedidos a la anatomía patológica. Época que marca la soberanía de la mirada, ya que, en el mismo campo perceptivo, siguiendo las mismas continuidades o las mismas fallas, la experiencia lee de golpe las lesiones visibles del organismo y la coherencia de las formas patológicas (Foucault, 2006, p. 17).

15 El problema del microscopio, antes que desembocar en una ruptura con el naturalismo ingenuo, devino en la necesidad de utilizar herramientas concretas para expandir la vista, sin dar cuenta del giro epistemológico ahí presente, es decir, sin reflexionar acerca de la cuestión de la invisibilidad en tanto virtual, por un lado, y la necesidad de un desarrollo semiótico para observar lo que antes era invisible, por el otro. No vemos con herramientas nada más, vemos con ojos virtuales (o más bien, con lentes virtuales) que proyectan imágenes históricamente producidas del mundo.

16 La cotidianidad se establece como mundo de sentido (Lebenswelt), como conjunto de prácticas en la vida cotidiana, que por ser inmediatas instauran cierta forma de ver la vida: el mundo de sentido (Husserl, 1998). En términos escópicos, esa cotidianidad está atravesada por ciertos cuidados en las prácticas, cuidados que implican que el otro no rebase esa zona de certeza; desde esta perspectiva, la realidad escópica es un discurso de verdad que hemos de seguir, pues garantiza la protección de nuestra vida (biopolítica). 
Algunos de estos regímenes escópicos "patologizantes" se presentan, de manera casi explícita, como curiosas mixturas en las cuales es difícil discernir las fronteras entre el espectáculo, el conocimiento y el simulacro. Un ejemplo de tales escenarios es el Hospital de la Pitié-Salpêtrière (conocido llanamente como La Salpêtrière), más específicamente el pabellón de las histéricas, lugar en donde, en el siglo XIX, el dolor y el saber se articularon performativamente bajo la dirección de Charcot, un famoso psiquiatra que contrató a fotógrafos y dibujantes para que retrataran las contracciones, los entrecejos fruncidos, las parálisis inmotivadas y los guiños inexplicables de aquellas mujeres que se sometían (algunas de ellas gustosamente) a la mirada escrutadora de los médicos.

Sobre todo, la fotografía sirvió a este fin: "Y es así como la fotografía se inventa como un ente científico, de amplias miras, generalizado, pese a que en su origen no es más que un acto ejemplar de la contingencia". (Didi-Huberman, 2007, p. 86). En este sentido, la fotografía, indudable ojo moderno por excelencia, adquiere poder de símbolo; a pesar de ello, se trata, más bien, de una intervención más solemne de lo imaginario, entendido como acto de la artificialidad (Didi-Huberman, 2007).

El indudable encanto, algo macabro, ejercido por esas imágenes capturadas entre los muros del pabellón de las histéricas de La Salpêtrière, da cuenta de

[...] algo que tiene que ver con la mirada, o más bien con un cruce entre mirada y representación [...] y es de este modo, con aspectos tomados de la mirada y el tiempo, como la fotografía se inventa una proximidad muy real con la locura (Didi-Huberman, 2007, pp. 90-91).

No cabe duda, entonces, de que la complejidad de los estudios visuales no es poca, y de que tal complejidad obedece, en gran parte, al entendimiento de los discursos científicos (entre ellos, los médicos) como espacios de configuración de saberes que devienen en formas de ver el cuerpo, de "reglamentar las condiciones de la visibilidad de los cuerpos sintomáticos y con el objeto de que proporcionaran signos y descripciones físicas" (Didi-Huberman, 2007, p. 80).

Por un lado, en la relación de la mirada con el cuerpo, surge la pregunta de por qué curar desde lo visible del cuerpo, es decir, desde la necesidad de tener cuerpos listos para la producción de visibilidad. Por otro lado, en el terreno de las continuidades de este saber médico, basadas en lo visual del cuerpo, la soberanía de la mirada atiende a lo que el discurso dice, a lo que está delante de los ojos, a la lectoescritura de la vista: faceta última de la comprobación científica, observación directa. Por último, tenemos no solo la observación directa de los cuerpos, sino también una observación entrenada en detectar patologías, una mirada del déficit, de lo anormal, del desarrollo exagerado o insuficiente.

La reflexión sobre lo virtual nos advierte que las cosas que estamos viendo obedecen a un régimen histórico de visibilidad que las establece, pero también que de ninguna manera esta forma de ver es la única, pues la visualidad, como toda materialidad, está atravesada por la historia; sobre todo, esta visualidad no es falsa, sino que está sostenida por prácticas cotidianas que defienden los cuerpos, y por múltiples teorías científicas que 
sostienen ese saber visual cotidiano. Aquí es donde surge el choque con la perspectiva del naturalismo epistemológico, para la cual "ver" entraña una suerte de privilegio semiótico de un individuo particular:

La vista ya no es, pues, el acto de un sujeto individual dotado de una facultad de "ver" que él podría ejercer sea en la atención sea en la distracción; la vista es el efecto de sus condiciones estructurales, la vista es la relación de reflexión inmanente del campo de la problemática con sus objetos y sus problemas. La visión pierde entonces sus privilegios religiosos de lectura sagrada, ya no es sino la reflexión de la necesidad inmanente que enlaza el objeto o el problema con sus condiciones de existencia, las cuales dependen de las condiciones de su producción (Althusser, 1978, p. 30).

El hecho de emplear la expresión "facultad de ver" para referirse a la capacidad de la visión da la impresión de que se trata de algo que no todos tienen, lo cual va en la misma línea de lo que propuso Althusser al respecto. En contraste, el análisis de los regímenes escópicos, apoyado en el campo de problemáticas inaugurado entre la reflexión y los objetos-problema de la vista, tiene en cuenta las condiciones de existencia que dotan de realidad a ciertas coordinaciones de imágenes. Tales coordinaciones son, en su complejidad, prácticas que producen sentido para sostener en una cotidianidad este régimen de visibilidad del mundo.

El régimen escópico es, en este orden de ideas, ese plus de virtualidad ${ }^{17}$ que produce el trabajo y sostiene una cotidianidad; es decir, una forma de ver el mundo. Así es como ciertos regímenes escópicos produjeron la visibilidad de ciertas realidades, que hasta entonces habían sido incógnitas, en el sentido de lo no conocido. Por ejemplo,

El patrón epistémico de la colonialidad del ver quedó sustentado desde entonces a partir de los siguientes elementos: 1) el reconocimiento del cuerpo y de la presencia de los indios caníbales como parte del mundo conocido, es decir, de la producción de la evidencia cartográfica, según la cual, el caníbal forma parte del "adentro" occidental, por un lado, y 2) en la producción de la evidencia etnográfica de que su existencia ontológica se ubica en un "afuera" absoluto e irreversible; en un más allá racial que no puede ser ni eliminado ni diluido por el proceso civilizatorio ni por la conquista violenta: este "más allá" dejó de ser un territorio (moral o físico) primitivo o lejano y se convirtió en un no-ser radical (Barriendos, 2011, p. 21).

La reflexión sobre los regímenes escópicos operantes pone en cuestión su carácter visualcentrista, que presenta la visualidad histórica contemporánea como un campo escópico construido desde la observación y la comprobación. En contraste, desde la lectoescritura o una teoría del signo, la visualidad no solo está centrada propiamente en

17 Aquí es importante el pasaje de la plus-valía al plus-de-goce (Lacan), como ese plus virtual, plus de sentido (Zizek, 2008), entendiendo el plus como Marx: como exceso (de capital/de sentido) que falta en alguna parte (del lado del proletario/falta de goce). Lo virtual implica también un exceso (proveniente de la virtualidad misma como productora de realidad) que conduce al reconocimiento de una falta (tal vez, precisamente de realidad). 
la vista, sino que está sostenida, como hemos señalado antes, por el nivel virtual de la formación perceptual ${ }^{18}$.

En la lógica anti-visualcentrista, los estudios visuales trascienden la identificación de cuerpos que perciben en una cotidianidad basada en la producción de ganancias, para pasar a referirse también a las condiciones de visibilidad necesarias para que este mundo adquiera movimiento y continuidad, para que adquiera realidad. La rigurosidad de tal lógica descansa sobre la consideración de los puntos ciegos de los regímenes escópicos, de lo llamado invisible, ya que "Lo invisible está definido por lo visible como su invisible, su prohibición de ver" (Althusser, 1978, p. 31). La invisibilidad es aquello que el régimen escópico niega, sesgo que se instaura al nivel de las imágenes (Zizek, 2008), y es la teoría como imagen del mundo la que establece los límites entre lo visible y lo invisible; por ello, valdría no decir vemos con los ojos, sino decir vemos con las imágenes que tenemos del mundo. En esta línea reflexiva, ciertos "ojos" como la cámara fotográfica no nos servirían siempre para ver más, pues al ponerse a servicio del visualcentrismo, constituirían "el aparato de un cogito enfermo de su propia certeza, caótico, desgarrado". (Didi-Huberman, 2007, p. 87).

\section{Tecnología del imaginario y ficción}

Un último problema que cierra nuestra explicación sobre la complejidad en el campo de los estudios visuales es el problema de la producción visual en relación con la lógica que opera en las formaciones discursivas; este nivel de la producción lo ubicamos en la teoría del trabajo y la producción del plus de realidad (Zizek, 2008).

El materialismo histórico, como ruptura epistemológica, en su ligazón crítica con las disciplinas hermenéuticas, explica la complejidad de la realidad desde el sentido como producto de la organización del trabajo de los hombres. En el trabajo, el humano produce las condiciones materiales bajo las cuales se construye la realidad: "El proceso de trabajo que da cuenta de la transformación infligida por el hombre a las materias naturales para hacer de ellas valores de uso y las relaciones sociales de producción". (Althusser, 1978, p. 183). En el trabajo hay una ganancia que se traduce en un plus valor, un algo más, relativo al sentido, con el que se puede producir realidad. Cada época histórica ha tenido un modo de producir ese sentido que la constituyó como "histórica", y que produjo también una forma natural de verse: cuando pensamos en un régimen escópico, entendemos la realidad como construcción desde esas estructuras escópicas supraindividuales que naturalizan los modos de ver y de verse ${ }^{19}$.

18 Se puede concluir que la semiótica no solo está en lo visual; es más, que puede prescindir de una visualidad ligada a los ojos como tal, pues una semiótica de los sueños o de los ciegos, se orienta a la capacidad abstracta o conceptual de dotar de sentido a los objetos, en conjunto con el resto de los sentidos, pero, sobre todo, desde la coordinación del cuerpo y considerando el plano de lo virtual: la visualidad desde el problema de la virtualidad, desde imágenes y espacios escópicos.

19 Útil revisar cómo se naturaliza el sentido común en la misma interacción de la vida cotidiana (Schutz, 2003). 
La teoría del trabajo, vista desde esta perspectiva, apunta a la comprensión de la formación del régimen escópico, un régimen escópico que produce productos que son colocados en el mercado y sostienen la cotidianidad del trabajador, la visión como puesta en escena en la producción. No hay trabajo sin trabajador: no hay trabajo abstracto, así como tampoco hay realidad sin imaginario; el régimen escópico produce las condiciones de visibilidad valiéndose de los imaginarios, a los cuales moldea mediante dispositivos tecnológicos.

Una tecnológica es una analítica de la complejidad que se juega entre imaginarios, visibilidad y tecnología:

Resulta absolutamente evidente que el gran impacto de la tecnósfera es la instauración de un modo diferente de articulación entre los procesos simbólicos que constituyen los bienes culturales y afectan los modos de producción y distribución de esos mismos bienes. Los paradigmas de la tecnología refieren a un mundo de relaciones y funciones que coloca entre paréntesis a la subjetividad. Es, en el modo de elaboración de lo objetivo y lo subjetivo, de lo finito a lo infinito donde se manifiestan las repercusiones del cambio de paradigma (Niederman, 2013, p. 37).

El régimen escópico produce tecnología, fruto del trabajo articulado en la mirada cotidiana del humano:

En nuestros imaginarios tecno-científicos las representaciones visuales y cuantitativas proponen y venden nuevos significados de objetividad y certeza. La tecnología se desarrolla impulsada por nuestras necesidades que, a su vez, lo son por nuestros deseos que, a su vez, son modelados por nuestros mitos (Anonymous, 2013, p. 433).

Lo que la mirada tecnológica produce son significados, son certezas de una realidad, de una forma de organizar los cuerpos, ajustados al consumo y al mito de la realidad dada. Este imaginario tecnológico perfecciona sus herramientas, ganancias y cotidianidades; la tecnología tiene que ver con la visibilidad de la realidad del consumo y la salud, de la vigilancia necesaria para producir la mayor cantidad de realidad posible ${ }^{20}$.

Si detectamos este régimen escópico como apoyado en una tecnológica que se encarga de sostener visualmente una producción de la realidad, ocultando nuevas posibilidades, podemos anunciar la necesidad de una formación teórica como alternativa reflexiva, o de transformación de dicho régimen, pues

Justamente, la iconósfera y la tecnósfera contemporáneas solicitan una reflexión sobre su impacto en la constitución de la subjetividad y en el desarrollo de las prácticas discursivas para dilucidar los distintos aspectos que, hoy, hacen a la sensibilidad, el pensamiento y la creatividad (Niedermaier, 2013, p. 33).

20 La referencia directa sobre una tecnológica, la tenemos en lo que Michel Foucault llamó: "tecnologías del yo" (1990). 
El problema de la visibilidad es que la tecnología no demanda teoría que visibilice su proceso de construcción de la realidad, sino que opera desde una lógica que mejore las condiciones, no que las transforme o las diluya. La tecnología demanda mejoramiento de la lógica vigente, demanda el último dispositivo: sus especialistas de dedican a refinar el discurso vigente.

$\mathrm{Si}$, tal como hemos reiterado a lo largo de este escrito, la realidad se construye y esta construcción depende de un plano virtual, o de formaciones del conocimiento (teorías) que visibilicen problemas contemporáneos, entre ellos el problema de la tecnología, entonces, en la producción de visualidad en la que participa el especialista, este ejerce una relevante injerencia en la construcción de las imágenes del mundo.

El imaginario es un espacio en disputa, abierto y en constante construcción, que afecta la forma de ver de los cuerpos, y que, determina sus prácticas, esto es, la organización del trabajo. La transdisciplina ${ }^{21}$ como movimiento contemporáneo que discute sobre los procesos de formación teórica contemporánea, permite visibilizar la complejidad de una mirada histórica, que tiene su base en imaginarios. Por ello, el movimiento transdisciplinar asume la reflexión sobre la creatividad que se presenta ante la construcción de la realidad desde imaginarios.

El imaginario en sentido transdisciplinario es el despliegue creativo de las imágenes del cuerpo, invitación a la creación, pues si la realidad está atravesada por el imaginario, esta se reconstruye hasta el infinito, como una suerte de rizoma orgánico y potencialmente "bifurcable":

El árbol lingüístico al modo de Chomsky aún comienza en un punto $S$ y procede por dicotomía. En un rizoma, a la inversa, cada rasgo no remite necesariamente a un rasgo lingüístico: eslabones semióticos de todas naturalezas están ahí conectados a modos de codificación muy distintos, eslabones biológicos, políticos, económicos, etc., poniendo en juego no sólo regímenes de signos diferentes, sino también, estatutos de estados de cosas. Las disposiciones colectivas de enunciación funcionan, en efecto, directamente en las disposiciones maquínicas, y no es posible establecer una ruptura radical entre los regímenes de signos y sus objetos (Deleuze y Guatari: 1996, p. 13).

Esta dimensión creativa del imaginario fue resaltada por el mismo Castoriadis, quien fue el que acuñó la expresión imaginarios sociales. Castoriadis señala al respecto, que lo central en la producción de imaginarios es el carácter indeterminado de toda significación (Cabrera, 2006), la invención incesante,

[...] social, histórica, psíquica de figuras, formas, imágenes, es decir, de producción de significaciones colectivas. Es capacidad imaginante de inventar lo nuevo; es social porque la capacidad imaginativa, propia del ser humano, es una facultad que se despliega en la vida histórica de las sociedades; es histórica

21 La transdisciplina es un movimiento contemporáneo de las ciencias y su reflexión sobre la especialización del conocimiento, discusión que se detiene en la falta de conexión entre las diferentes disciplinas científicas y áreas del conocimiento en general. 
porque el hombre es consciente de su tiempo, porque se construye en el tiempo, porque configura su historia; es psíquica porque es fuente de representaciones que no obedecen a una lógica ortodoxa (Agudelo, 2011, p. 9).

En la discusión entre Lacan y Castoriadis, se pone de manifiesto que para el primero la dimensión imaginaria es pura alienación, ilusión discursiva proveniente del otro y del Otro; mientras, para el segundo el imaginario es pura creatividad:

Así, la primera divergencia entre Lacan y Castoriadis es del orden de la filosofía, es metapsicológica: para Lacan la psique es actividad especular y para Castoriadis la psique es flujo irrefrenable. Estamos en el nudo de un asunto muy pesado, porque Lacan descarta -o deja fuera- de plano aquellas representaciones que en realidad son presentificaciones emergentes de la psique; imágenes que, aunque respondieran a una pulsión o deseo -y no siempre es así-, serían creaciones con varios destinos posibles, uno de los cuales sería la réplica de la realidad. Por otra parte, Castoriadis no solo no descarta estas emergencias, sino que afirma que aquello que las hace características es que son expresiones de una imaginación radical no funcional (Aponte, 2014, p111).

Este contraste, lejos de obstaculizar la reflexión, anima el debate sobre lo que se produce de novedoso en el proceso de constitución de los imaginarios, y conduce a una posible conciliación, no libre de tensiones, entre lo que puede considerarse la faceta rizomático-creativa de los imaginarios, y su vertiente enajenante; es decir, la diferencia entre Castoriadis y Lacan conduce en último término al reconocimiento de la dimensión creativa de los imaginarios, sin desconocer su origen en algo que no es propiamente el sujeto mismo.

La transdisciplina contribuye a este proceso de reconocimiento sin desconocimiento, al invitar a la creación en sentido denso, a partir de la mezcla compleja de imágenes provenientes de diversos campos de la praxis (incluyendo la praxis teórica), de tal forma que la pregunta no pasa por descubrir la realidad, sino por re-inventarla. Ello no implica abandonar las categorías lingüísticas para entender un discurso, sino hacer pasajes-recorridos por eslabones semióticos que se dejan atravesar por diferentes disciplinas: (biología, política, economía, entre otras), logrando jugar con los regímenes de signos, con el estatuto de las cosas, alterando radicalmente la relación entre los signos y los objetos ${ }^{22}$.

La transdisciplina como imaginario supone una necesidad de creación conceptual, necesidad como ejercicio del nivel imaginario capaz de visibilizar puentes entre los diferentes conocimientos, mismos que permiten, a su vez, visibilizar niveles de complejidad. Ta pretensión es coherente con la postura de Morin frente al pensamiento complejo: "La ambición del pensamiento complejo es rendir cuenta de las articulaciones entre dominios

22 Pensar sobre la lógica del rizoma, donde el trayecto es lo importante, y los puntos de inflexión; la ficción desde un cine como transdisciplina, donde lo que importa es la conexión, el sentido, no, la verdad de la representación. La zona maquínica como la zona semiótica de abandono a la representación humana como tal, con la cámara de video, tenemos el registro de algo no humano, que entonces se compromete con el imaginario, antes que con la verdad o, de otra manera, se desplaza la verdad a la imagen: régimen escópico. 
disciplinarios quebrados por el pensamiento disgregador o simplificador (que aísla lo que separa y oculta todo lo que religa, interactúa o interfiere), éste aspira al conocimiento multidimensional" (Rueda Ortiz, 2007, p. 329). En cada nueva conexión, en cada nuevo puente, se crea desde esta perspectiva (literalmente) un punto de fuga en el régimen escópico, punto de fuga que visibiliza algo nuevo, o que ayuda a ver de manera diferente eso que ya estaba.

Pensar las ciencias desde la complejidad nos ofrece nuevos accesos a diferentes niveles en la posibilidad de construcción de la ciencia misma; por un lado, permite pensar horizontes transdisciplinarios que entramen diferentes conceptos y doten de distinto sentido las teorías previas; por el otro, traslada objetos de estudio, métodos e instrumentos que ayudan a resolver los problemas que incumben a una ciencia ${ }^{23}$ (Piaget y García, 2008).

La incidencia de los estudios visuales en este plano de la complejidad de las ciencias la plantemos en esta zona de la formación de la visualidad, es decir, en las conceptualizaciones de los procesos contemporáneos que decanten en una percepción abstracta que pueda asimilar la densidad tecnológica. En esta lógica, la formación de la visualidad la ligamos a una formación teórica que permita la construcción de objetos de estudio, o de análisis ${ }^{24}$ :

La pregunta que en la actualidad le plantea la decolonialidad a los estudios visuales parece ser, entonces, si la desinvisibilización de la matriz de poder de la mirada etnográfica occidental puede articularse como la vuelta de tuerca en la consecución de un nuevo diálogo interepistémico entre culturas visuales eurocentradas y culturas visuales que fueron racialmente inferiorizadas, a través de las tecnologías moderno/coloniales del ver. En este sentido, el reconocimiento de la colonialidad del ver debe conducirnos hacia el "descubrimiento" de paradigmas escópicos adyacentes, alternativos y contestatarios, inscritos pero invisibilizados - por el desarrollo histórico de la modernidad/colonialidad. (Barriendos, 2011, p. 25).

Cuando entendemos que los objetos son construcciones cognitivas, entendemos también que ellos aparecen ante nuestros ojos cuando se entraman en problemas que estaban, pero no eran vistos o, por expresarlo en términos diferentes, que no estaban presentes de esa manera, a modo de problemas. En este orden de ideas,

[...] todo planteamiento fundamentalmente nuevo de los problemas científicos, conduce a nuevos métodos y técnicas de investigación. El objeto y le método de investigación mantienen una relación muy estrecha. Por ello, la investigación adquiere una forma y curso completamente nuevo, adecuado al nuevo problema; en este caso la investigación se diferencia sustancialmente

23 La expansión transdisciplinaria que se esfuerza por resolver los viejos problemas de las diferentes ciencias, así como la generación conceptual de nuevos niveles de complejidad mediante una reflexión que vaya más allá de los límites entre campos científicos, una transdisciplina implica compartir, reflexionar y transformar los diferentes niveles de las ciencias: nivel teórico, metodológico y de objetos de estudio.

24 Podemos ubicar un movimiento hacia una geografía cognitiva capaz de seguir el proceso en la construcción del espacio del sujeto epistemológico que permite generar nuevas herramientas en la comprensión de la visualidad, así como debates en torno a la construcción del campo escópico. 
de aquellas formas en las que el estudio simplemente aplica a las nuevas áreas los métodos ya elaborados y establecidos en la ciencia (Vygotski, 2000, p. 47).

La transdisciplina logra generar nuevas herramientas analíticas, desde métodos, teorías o técnicas, implicando que las ciencias se construyan conforme al problema, y no al revés. Así, la investigación transdiciplinar busca salir de los métodos ya elaborados, y se compromete más con visibilizar nuevos problemas. He ahí su horizonte radicalmente creativo, por retomar la expresión de Castoriadis. En este espacio creativo de incidencia transdisciplinar, no solo teórico, sino también político, la construcción de objetos de análisis incluye el campo escópico atravesado por el signo, pues "solo existe lingüísticamente lo que es percibido por la conciencia, es decir, lo que es o se convierte en signo" (Saussure, 2004, p. 49).

Si la ciencia es un sistema sociocultural construido semióticamente, entonces sus transformaciones nos permiten comprender también las transformaciones de la realidad. Una ciencia desde la transdisciplina está comprometida con la invención, teniendo en cuenta que "Inventar es, finalmente, toparse y caer, en seco, al chocar con la cosa, con la cosa misma; es volver sobre ella, invenire, y desvelarla, quién sabe..." (Didi-Huberman, 2007, p. 12). Inventar es, entonces, volver sobre la cosa indecible, sobre lo real, para intentar apresarlo con el lenguaje visibilizando nuevos problemas, lo cual se traduce en ampliación y reestructuración de los esquemas semióticos. Esta ampliación dota al investigador de nuevas herramientas para pensar los problemas contemporáneos:

La transformación de la matriz teórica del planteamiento de todo problema concerniente al objeto, concerniente a la realidad del objeto: a su definición objetiva [...] La transformación del objeto hace visible, en el objeto, nuevos aspectos que antes no eran en absoluto visibles; ocurre con el objeto lo mismo que con los mapas geográficos de regiones aún mal conocidas pero que se exploran (Althusser, 1978, p. 169).

La transdisciplina, como modo comprometido con la complejidad de enfrentar el régimen escópico, permite hacer ver nuevos problemas o hacer ver los ya existentes de otra manera, analizando la visibilidad propia de cada época, sus posibilidades y sus contradicciones, pero también los propios horizontes de visibilidad del abordaje transdisciplinario, desde una dimensión, si puede decirse, metavisual, sin por ello afirmar que la transdisciplina posea la visión correcta o verdadera de la realidad, pues ello sería caer en el mismo error del naturalismo retiniano de la visión.

Esta dimension metavisual, en el sentido de una conciencia de los mecanismos visuales que operan tras la manera de ver propia de la transdisciplina posibilita desentrañar los efectos de la analítica del sentido, que sirvan como herramientas cognitivas en la transformación de los límites invisivilizados:

La imagen en este sentido debe devenir, ser devenida en objeto creativo y de estudio (espíritu de la Bildwissecnshaft), de lo contrario, lo que viene es simplemente repetición sofisticada de los sistemas de dominación y de captura 
de la subjetividad por todos conocidos... una técnica y un dispositivo de las industrias culturales (Rodríguez, 2011, p. 78).

Si ubicamos el problema de las industrias culturales como regímenes escópicos, es decir, como formas de dominación visual casi innatas e invisibles, el espacio de la ficción nos ofrece una nueva apertura, siempre latente, en la configuración del régimen escópico desde el plano del imaginario, la distorsión, la carga teórica y la formación transdisciplinaria, lo cual nos posibilita configurar una epistemología de la imagen propositiva, rizomática, creativa.

\section{Reflexiones finales}

Hemos analizado el campo del pensamiento visual contemporáneo desde el problema mismo de la visualidad, entendido como un proceso complejo que parte de imaginarios en y del cuerpo, articulados desde un régimen escópico que funciona como pauta de representaciones que estructuran la percepción. La cotidianidad naturaliza la percepción, invisibilizando la relación que hay entre imaginario y régimen escópico. Tal cotidianidad decansa sobre el supuesto de la visión como proceso natural, fisiológico; no obstante, antes que natural, la visión presenta una configuración histórica específica, cargada de intereses políticos y producida bajo ciertas condiciones socioculturales, por lo cual deviene, precisamente, visualidad.

El giro epistemológico ${ }^{25}$, la revolución hermenéutica, considerada más allá de las fronteras de un movimiento filosófico situado históricamente en el siglo XX, nos permite entender la visualidad como una construcción de sentido; así, la realidad está basada en una interacción densa entre imaginarios y regímenes escópicos, relación que abre en ella una brecha real, cubierta por un decorado fantasmal y de ficción. Cuando el decorado cae, como en los momentos de angustia que caracterizan la alucinación o el agrietamiento de cualquier sistema teórico (la caída kuhniana de un paradigma es un ejemplo claro), aflora lo real y el observador queda en el lugar del objeto, siendo mirado en lugar de ver.

La mirada, entendida como contraparte real de la visión, muestra entonces las raíces fragmentadas de tal visión, no accesibles al cuerpo mismo de la percepción, en el cual las huellas mnémicas pertenecen al límite entre las coordinaciones del cuerpo que devienen en imágenes, y lo no coordinado: un espacio de distorsión, de incoordinación. Este espacio de distorsión éxtimo (siguiendo una locución lacaniana que da cuenta de esa zona de confluencia entre lo familiar y lo ajeno), es lo más cercano, al mismo tiempo que lo más extraño al cuerpo; es un espacio más allá del sujeto y del objeto, llamado régimen escópico, lugar del tercero que participa implícitamente en la percepción.

Ese espacio es lo que actualiza la imagen y la coordina como vida cotidiana. Entender la visualidad desde este Gran Otro estructurante e implícito, pero también desde los niveles de reestructuración de los esquemas semióticos más íntimos y subjetivos, por

25 Las rupturas epistemológicas que superaron el método científico: psicoanálisis, sistemas complejos, fenomenología, materialismo histórico, hermenéutica. 
llamarlos de alguna manera, es entender la complejidad de la mirada que no acaba en el imaginario, sino en su constitución fantasmagórica y virtual para cubrir, precisamente, la alienación proveniente de un tercero. El giro transdisciplinario, como consecuencia radical del giro epistemológico, abre las fronteras del conocimiento, y nos permite acceder a este nivel de complejidad en la comprensión de la realidad. La apuesta de la transdisciplina se suscribe, para lograr tal cometido, del lado de la creación, de la ficción: ahí donde no se trata ya de descubrir la realidad, sino de inventarla y re-inventarla.

\section{Conclusiones}

Los imaginarios revelados en el discurso de los participantes mostraron una complejidad que rebasó las categorías de análisis, las cuales fueron insuficientes y restrictivas a la hora de abordar las expresiones verbales y no verbales de los participantes sobre los contenidos de los comerciales televisivos. Esa complejidad se mostró constituida, en gran parte, por paradojas propias de las condiciones subjetivas puestas de manifiesto durante las sesiones.

Una de esas paradojas, reiterativa, fue la de una necesidad de límites, de la presencia de un Otro (Gran otro) contenedor, casi siempre puesto del lado de los adultos, encargado de establecer las normas y esbozar un camino orientador. Los participantes en los grupos focales plantearon una crítica a la adultez contemporánea, empeñada en perpetuar su juventud, actitud producto del relato publicitario mismo, que propone una sociedad "forever young".

Ese Otro cuya legislación se reclama, pero que en la realidad está quebrado, que muestra sus inconsistencias, se presenta como lugar de la diferencia, pero también de la identificación; de la orientación activa, pero además, de la flexibilidad. Es, tal vez, un nuevo Otro encargado de arrojar luces ante la ambigüedad de los relatos publicitarios contemporáneos, pero también de alejarse cuando sea necesario, evitando el carácter opresivo tradicional atribuido a tal concepto. En este sentido, el reclamo a un Otro se muestra como paradojal, incluso como imposible, lo que no lo hace inválido.

Ese Otro se evidenció, además, como una presencia omnisciente, contenida en un ojo que todo lo ve y que convierte en espectáculo la vida privada. La presumible libertad de toda atadura social, todavía esgrimida como fortaleza de la juventud, se vierte en una vitalidad que al mismo tiempo se oculta como íntima y se expone al espacio de lo público como insignia identificatoria de un "nosotros" que contrasta con un "ellos" (los adultos, la sociedad, las instituciones; en fin: ese Otro que precisamente tanto se invoca en el discurso como necesario).

En todo caso, los imaginarios de juventud necesitan de esa suerte de aparato "ortopédico" que es el Otro (garante de la autoridad, de la seguridad, de la protección familiar) para construirse. Empero, justamente lo más familiar deviene con más fuerza extraño, contradicción propia de los procesos de subjetivación y socialización, en los que suele desconocerse la contribución de lo ajeno a lo propio, para preservar la identidad consigo mismo o con el grupo de referencia. Lo ortopédico es considerado, en este orden de ideas, 
como algo que no es propio, con respecto a lo cual cabe incluso resistirse: algo extraño, venido del exterior que, sin embargo, ayuda a mantener una postura "correcta"; de ahí el uso que hemos dado a esta noción aquí, acorde con la expresión que Lacan emplea para referirse a la figura que sostiene al niño jubiloso frente al espejo, mientras reconoce su imagen en él.

Los efectos de reconocimiento (identidad e identificación), conocimiento (carácter epistemológico) y desconocimiento (condición de una subjetividad escindida) de ese Otro identificado en los imaginarios de juventud construidos por los participantes en la investigación se aúnan al talante activo de un potencial consumidor. La alienación radical que implica esa participación, descrita en líneas anteriores, de un Otro ajeno en la construcción de la subjetividad o "grupalidad" propias, se muestra en tensión con respecto a la resignificación de las intenciones publicitarias. Los jóvenes consumidores de nuestros tiempos no se muestran tan fácilmente convencidos por las imágenes y mensajes publicitarios, o al menos exigen elaboraciones más complejas que las meramente destinadas a la persuasión directa. Por ello, tendieron a identificar e identificarse con, conocer con mayor agrado y desconocer menos los contenidos de comerciales en los que las experiencias (supuestas) juveniles de se privilegian por encima de la marca o el producto.

No obstante, estos matices de creatividad radical, lejos de tranquilizarnos como investigadores, nos pusieron en alerta, pues señalaron hacia una posible complicidad entre el relato publicitario contemporáneo, siempre en guardia, y las condiciones históricas presentes, productoras de nuevas subjetividades, en apariencia más críticas, menos pasivas. Ese, sin embargo, es un asunto que excede los límites de esta indagación.

\section{Referencias}

Agudelo, P. (2011). (Des)hilvanar el sentido/los juegos de Penélope. Una revisión del concepto de imaginario y sus implicaciones sociales. Uni-Pluri/Versidad, 11 (3), 1-18.

Althusser, Louis (1978) Para leer el capital. Siglo XXI: México.

Amozurrutia, José (2011) Complejidad y ciencias sociales: un modelo adaptativo para la investigación interdisciplinaria. CEIICH-UNAM: México

Anonymous (2010) Imaginarios: Teorías. En: Gac Sanit v. 24 n .5 Barcelona set.-oct. 2010. ISSN 0213-9111.

Aponte, M. (Enero de 2014). Diálogo: Castoriadis versus Lacan. Recuperado de https://economiapoliticaehucv. wordpress.com/2014/01/06/dialogo-castoriadis-versus-lacan/

Biosca, A. (2009). Mil años de virtualidad: origen y evolución de un concepto contemporáneo. En Eikasia. Revista de Filosofía, IV (26). Disponible en http://revistadefilosofia.com/28-01.pdf

Brea, José Luis (2007). Cambio de régimen escópico: del inconsciente óptico a la e-image. Estudios visuales: Ensayo, teoría y crítica de la cultura visual y el arte contemporáneo 4, 145-163.

Bachelard, Gaston. (2004) Estudios. Amorrortu: Buenos Aires.

(2009) La filosofía del no. Amorrortu: Buenos Aires. 
Barriendos, Joaquín (2011) La colonialidad del ver. Hacia un nuevo diálogo visual interepistémico. En Nómadas $n .^{\circ} 35$ Bogotá July/Dec. 2011. ISSN 0121-7550

Bergson, Henri. (2006) Materia y memoria: ensayo sobre la relación del cuerpo con el espíritu. Cactus: Buenos Aires.

Cabrera, D. (s. f.). Imaginario social, comunicación e identidad colectiva. Recuperado de http://www. portalcomunicacion.com/dialeg/paper/pdf/143_cabrera.pdf

Deleuze, G. y Guatari, F (1996) Rizoma: Introducción. Pre-textos: Valencia.

Didi-Huberman, G. (2007). La invención de la histeria. Charcot y la iconografía fotográfica de la Salpêtrière. Madrid- Cátedra.

Foucault, Michel (2006) El nacimiento de la clínica. Siglo XXI: México.

(2009 [1]) El orden del discurso. Tusquets: Barcelona.

(2001) La arqueología del saber. Siglo XXI: México.

(2006) La naturaleza humana: justicia versus poder, un debate. Noam Chomsky | Michel Foucault. Katz: Argentina

(2013) ¿Qué es usted, profesor Foucault?: sobre arqueología y su método. Siglo XXI: Argentina.

(1990) Tecnologías del yo. Y otros textos afines, Barcelona: Paidós

(2009 [2]), Vigilar y castigar: el nacimiento de la prisión. Siglo XXI: México.

Freud, Sigmund (2003) El yo y el ello. Alianza: Madrid.

García de Mendoza, Alberto (2004) Filosofía moderna: HUSSERL, SCHELER, HEIDEGGER. Morelia Editorial: México.

García, Rolando (2008) Sistemas complejos: conceptos, método y fundamentación epistemológica de la investigación interdisciplinaria. Barcelona: Gedisa.

Gros, Fréderic. (2007) Michael Foucault. Amorrortu: Buenos Aires.

Hacking, Ian. (2006) La domesticación del azar. La erosión del determinismo y el nacimiento de las ciencias del caos. Gedisa: Barcelona.

Hernández, G; y Rodríguez, L (2003) Filosofía de la experiencia y ciencia experimental. FCE: México.

Husserl, Edmund (1998) Invitación a la fenomenología. Paidós: Barcelona.

(2009 [1]) Las conferencias de París: Introducción a la fenomenología trascendental. UNAM, Instituto de investigaciones filosóficas: México.

(2009 [2]) Lógica formal y lógica trascendental. UNAM: Instituto de investigaciones filosóficas: México. 2009 [2]

Jay, M. (2007). ¿Parresía visual? Foucault y la verdad de la mirada. Estudios visuales: Ensayo, teoría y crítica de la cultura visual y el arte contemporáneo 4, 7-22.

Kant, I (2006) Crítica a la razón pura. Taurus: México.

Lacan, Jaques (2005 [1]) El estadio del espejo como formador de la función del yo [jel tal como se nos revela en la experiencia psicoanalítica. En: Escritos I. Siglo XXI: México. 
(2005 [2]) Observación sobre el informe de Daniel Lagache: "Psicoanálisis y estructura de la personalidad. En Escritos II. Siglo XXI: México.

Lacan, J. (2006). El seminario, Libro 10: La angustia. Buenos Aires: Paidós.

(1995). El Seminario, Libro 11: Los cuatro conceptos fundamentales del psicoanálisis. Buenos Aires: Paidós.

Martínez Velasco, J. (1992). Bachelard, Popper y el compromiso racionalista de la ciencia. En: Convivium 3: 75-97.

Niedermaier, Alejandra (2013) La distribución de lo inteligible y lo sensible hoy. En Cuad. Cent. Estud. Diseño Comun., Ens. N. ${ }^{\circ} 43$ Ciudad Autónoma de Buenos Aires Jan./Mar. 2013. ISSN 1853-3523

Padilla, Hugo (2006) Ideas axiológicas en las primeras obras de Husserl. Morelia editorial: México.

Padrón, J. (2007). Tendencias Epistemológicas en la investigación científica en el siglo XXI. En: Cinta de Moebio 28: 1-28. Disponible en www.moebio.uchile.cl/28/padron.html

Piaget, Jean. (2008) Biología y conocimiento. Siglo XXI: México.

Piaget, J., y R., García (2008) Psicogénesis e historia de la ciencia. Siglo XXI: México

Piaget, J, y B, Inhelder. (2007) La función semiótica. En Psicología del niño. Morata: Madrid.

Rechardt, Ecero (1998) Los destinos de la pulsión de muerte. En: La pulsión de muerte. Amorrortu: Buenos Aires.

Rodríguez, Edgar (2011) La imagen que viene: un régimen escópico entre la Bildwissenschaft y los "pequeños monstruos". En Nómadas $n .^{\circ} 35$ Bogotá July/Dec. 2011. ISSN 0121-7550

Rueda Ortiz, Rocío (2007) Para una pedagogía del hipertexto. Anthropos: Barcelona.

Sáenz, J. y Lasuén, M. (2004). El amuleto fálico de oro de Bilbilis (Calatayud-Zaragoza). En Saldvie 4, 221-227.

Saussure, Ferdinand (2004) Escritos sobre lingüística general. Gedisa: Barcelona. 2004.

Steiner, G. (2003). Lenguaje y silencio. Ensayos sobre la literatura, el lenguaje y lo inhumano. Barcelona: Gedisa.

Vygotski, Lev (2000) Historia del desarrollo de las funciones psíquicas superiores. En Obras escogidas tomo III. Editorial Pedagógica: Madrid.

Zizek, Slavoj (2008) Cómo leer a Lacan, Barcelona: Paidós.

Notas 